\title{
Grounding and Shielding in the Accelerator Environment
}

\author{
Q. Kerns \\ Fermi National Accelerator Laboratory \\ P.O. Box 500, Batavia, Illinois 60510
}

Presented at the 1991 Accelerator Instrumentation Workshop, CEBAF, Newport News, Virginia, October 28-31, 1991. 


\section{Disclaimer}

This report was prepared as an account of work sponsored by an agency of the United States Government. Neither the United States Government nor any agency thereof, nor any of their employees, makes any warranty, express or implied, or assumes any legal liability or responsibility for the accuracy, completeness, or usefulness of any information, apparatus, product, or process disclosed, or represents that its use would not infringe privately owned rights. Reference herein to any specific commercial product, process, or service by trade name, trademark, manufacturer, or otherwise, does not necessarily constitute or imply its endorsement, recommendation, or favoring by the United States Government or any agency thereof. The views and opinions of authors expressed herein do not necessarily state or reflect those of the United States Government or any agency thereof. 


\title{
GROUNDING AND SHIELDING IN THE ACCELERATOR ENVIRONMENT
}

\author{
Quentin A. Kerns \\ Fermi National Accelerator Laboratory; Batavia, Illinois 60510-0500*
}

\begin{abstract}
Everyday features of the accelerator environment include long cable runs, high power and low level equipment sharing building space, stray electromagnetic fields and ground voltage differences between the sending and receiving ends of an installation. This paper pictures some Fermilab installations chosen to highlight significant features and presents practices, test methods and equipment that have been helpful in achieving successful shielding. Throughout the report are numbered statements aimed at summarizing good practices and avoiding pitfalls.
\end{abstract}

\section{INTRODUCTION}

The need to consider shielding was impressed on me 40 years ago when for three weeks a betatron failed to achieve full energy despite checking and rechecking. It turned out the machine had been working all the time; what had happened was that the phototubes being used for beam observation were cut off by the stray field of the magnet about two-thirds of the way up to full energy. I never forgot it. Over the years I found out from experts how to design and use magnetic shields.

All figures mentioned follow the body of the text.

Figure 1 is an aerial view of the Fermilab accelerator complex with its 1000 meter radius rings. In the lower center we see the triangular P-bar source and at its left the Booster ring, the Linac and the High-Rise building, facing out over the external beam lines. There are many miles of signal and timing cables encircling the Main and the Tevatron rings and tracing the beam line. A new generation of accelerators replaces many of these cables with fiber optics runs ${ }^{1}$. Here, however, we will discuss the profusion of cables, buses, coaxial lines and waveguides that remain as needed items, not displaced by fiber optics.

Power lines are and will be needed in present and future accelerators. Figure 2 shows the Fermilab master substation. Site power enters on 345 $\mathrm{KV}$ high lines on graceful white poles. There are five 40MVA and one 60 MVA transformers, stepping the $345 \mathrm{KV}$ down to $13.8 \mathrm{KV}$ for underground feeder distribution. Without going into details of all the loads, let me describe two.

The pulsed power load for the main ring is fed separately by XFMR 82B. The P-bar source has its own transformer, 83A.Thus there is some isolation between "noisy" power and "quiet" power. This idea is continued at the $13.8 \mathrm{KV}$ to $480 \mathrm{~V}$ substations; where there is a need to distinguish "quiet" from "noisy" loads, two separate $480 \mathrm{~V}$ transformers are placed outdoors at a service building. Indoors, the direct $480 \mathrm{~V}$ and 208-120V stepdown 
transformers feed the local power loads. Often the loads are SCR or chopper supplies that could cause line noise unless filtered. A good rule is:

(1) Know the power source for your equipment and plan for filters, voltage regulation and non-interruptible power as needed.

\section{EMI GENERATORS}

The accelerator environment is not an electronic clean room. We tend to be our own worst enemy. See Table 1 for some devices that produce conducted or radiated electromagnetic interference, or EMI. For brevity, the list includes just a few sources, less than $1 \%$ of the total.

Table 1.

\section{A FEW EMI GENERATORS}

\begin{tabular}{|c|c|c|c|c|c|c|}
\hline MACHINE & $\begin{array}{l}\text { GENERA- } \\
\text { TOR }\end{array}$ & $\begin{array}{c}V, I \text {. } \\
\text { FREQUENCY }\end{array}$ & $\begin{array}{l}\text { CABLEOR } \\
\text { TRANS- } \\
\text { MISSION } \\
\text { LINE }\end{array}$ & $\begin{array}{l}\text { GOOUNOED } \\
\text { OR } \\
\text { FLOATING }\end{array}$ & NOTES & $\begin{array}{l}\text { GROUND } \\
\text { FAULT } \\
\text { PROTEC. } \\
\text { TION }\end{array}$ \\
\hline $\begin{array}{c}\text { Tevatron } \\
\text { RF } \\
\end{array}$ & $\begin{array}{l}150 \mathrm{KW} \\
\text { Tetrode } \\
\end{array}$ & $53 \mathrm{MHz}$ & $\begin{array}{l}9 \text { inch } \\
\text { coax } \\
\end{array}$ & Grounded & $\begin{array}{c}\text { D.C. flange } \\
\text { test }\end{array}$ & $\mathrm{NO}$ \\
\hline $\begin{array}{l}\text { Main Ring } \\
\text { RF }\end{array}$ & $\begin{array}{l}150 \mathrm{KW} \\
\text { Tetrode }\end{array}$ & $53 \mathrm{MHz}$ & $\begin{array}{c}\text { None-Dir. } \\
\text { coupled to } \\
\text { cavity }\end{array}$ & Grounded & $\begin{array}{l}\text { D.C. flange } \\
\text { test }\end{array}$ & NO \\
\hline $\begin{array}{l}\text { Booster } \\
\text { Bias }\end{array}$ & SCR Supply & $\begin{array}{r}0.2500 \mathrm{~A} \\
30 \mathrm{~V}, 15 \mathrm{~Hz}\end{array}$ & \begin{tabular}{|l|l|}
$1 / 4 \times 4^{n}$ \\
Bus \\
\end{tabular} & Floating & $\begin{array}{l}10 \mathrm{~K} \text { Resis- } \\
\text { tors to gnd }\end{array}$ & YES \\
\hline $\begin{array}{c}\text { Booster } \\
\text { Guide Field }\end{array}$ & SCR Supply & $\begin{array}{c}67.5 \mathrm{~A} \text { to } \\
970 \mathrm{Amps} \\
15 \mathrm{~Hz}\end{array}$ & $\begin{array}{c}750 \mathrm{MCM} \\
\text { water- } \\
\text { cooled bus }\end{array}$ & Floating & $\begin{array}{l}\text { Resistors } \\
\text { to ground }\end{array}$ & YES \\
\hline $\begin{array}{c}\text { Booster } \\
\text { Kicker } \\
\text { MKO5 }\end{array}$ & Thyratron & $\begin{array}{c}60 \mathrm{KV} \\
1.699 \mu \mathrm{sec} \\
\text { cable PFN }\end{array}$ & $\mathrm{RG} / 220 \mathrm{U}$ & $\begin{array}{c}\text { Supply } \\
\text { grounded, } \\
\text { kicker fl. }\end{array}$ & $\begin{array}{c}\text { Current } \\
\text { waveform } \\
\text { monitor }\end{array}$ & NO \\
\hline $\begin{array}{l}\text { Linac Up- } \\
\text { grade } \\
\text { Quads }\end{array}$ & $\begin{array}{c}\text { Switched } \\
\text { cap banks, } \\
2 \text { msec at } \\
\text { base }\end{array}$ & $\begin{array}{l}175 \mathrm{~A} \text {, flat } \\
\text { top. } 870 \mathrm{~V} \\
15 \mathrm{pps}\end{array}$ & $\begin{array}{l}3 / 4^{*} \text { Tri- } \\
\text { axial cable }\end{array}$ & $\begin{array}{l}\text { (-)P.S. } \\
\text { terminal } \\
\text { grounded; } \\
\text { mag. coil } \\
\text { floating }\end{array}$ & $\begin{array}{l}\text { Triaxial } \\
\text { outerbraid } \\
\text { grounded, } \\
\text { both ends }\end{array}$ & NO \\
\hline $\begin{array}{l}\text { Linac Up- } \\
\text { grade RF }\end{array}$ & $\begin{array}{c}12 \mathrm{MW} \\
\text { klystron }\end{array}$ & $\begin{array}{c}805 \mathrm{MHz} \\
125 \mu \mathrm{sec} \\
15 \mathrm{pps}\end{array}$ & $\begin{array}{l}\text { WR-975 } \\
\text { waveguide }\end{array}$ & $\begin{array}{l}\text { Grounded, } \\
\text { both ends }\end{array}$ & $\begin{array}{l}\text { D.C. flange } \\
\text { test, RF } \\
\text { flange test }\end{array}$ & NO \\
\hline $\begin{array}{l}\text { Linac Up- } \\
\text { grade } \\
\text { Modulator }\end{array}$ & $\begin{array}{l}24 \mathrm{MW} \\
\text { PFN }\end{array}$ & $\begin{array}{c}125 \mu \mathrm{sec} \\
\text { pulse at } \\
15 \mathrm{pps}\end{array}$ & $\begin{array}{c}\text { Shielded } \\
\text { RG/220 } \\
\text { pair }\end{array}$ & $\begin{array}{l}\text { (-)Termin. } \\
\text { grounded } \\
\text { only at } \\
\text { klystron } \\
\text { xfmr }\end{array}$ & $\begin{array}{l}\text { Triaxial } \\
\text { outer braid } \\
\text { grounded, } \\
\text { both ends }\end{array}$ & NO \\
\hline $\begin{array}{l}\text { Drift-tube } \\
\text { Linac } \\
\text { Debuncher }\end{array}$ & $\begin{array}{l}100 \mathrm{KW} \\
\text { Tetrode }\end{array}$ & $201 \mathrm{MHz}$ & $\begin{array}{c}31 / 8^{n} \\
\text { Rigid coax, } \\
3^{n} \text { Heliax }\end{array}$ & $\begin{array}{l}\text { Grounded, } \\
\text { both ends }\end{array}$ & & NO \\
\hline
\end{tabular}


Take the first and second columns of Table 1 as potential EMI generators. Consider that the group of people designing them may not be the same as the group designing the low-level instrumentation. Rule:

(2) Get these groups together, early in the design stage of the highpower equipment. Set goals for permissible radiated and conducted EMI from the high power equipment.

\section{LOW LEVEL-HIGH POWER JUXTAPOSITION}

The central problem is that high power equipment tends to interfere with low level instrumentation. In Figure 3, Typical Accelerator Environment, consider that the box labeled "Power Supply" could be any of the items described in Table 1, column 2. The goal is to minimize electrical noise pickup at the instrument racks, where sensitive circuitry may be observing small signals from a detector in the tunnel. The booster (ferrite) bias supply is an example from Table 1. Figure 4 shows the top of this Ferrite Bias Supply, $30 \mathrm{~V}$ at $2500 \mathrm{Amps}, 15 \mathrm{~Hz}$. The black cylinder in the foreground is the 2500 Amp transductor. The $1 / 4$ " $\times 4$ " busbar pair emerges from the left foreground single-bolt connector and vanishes in the background, heading down the penetration into the Booster tunnel.

The complete current loop of the 2500A supply upstairs in the Booster gallery, down to the ferrite-cored load in the tunnel 25 feet below, is floating. The only connection to ground is a pair of $10 \mathrm{~K} \Omega$ resistors across the power supply terminals to permit ground fault detection. When these soft ground resistors are lifted, the power supply and load can be hi-potted and tested with a megohm meter to verify isolation from ground. The aim of the floating circuitry is to eliminate ground currents. The busbar circuit net enclosed area is kept small to reduce stray magnetic field and the beam pipe is effectively magnetically shielded with a long Permalloy cylinder. The conducted ground current is a displacement current of about 250 microamps, $140 \mathrm{~dB}$ below the load current and certainly not troublesome. What can we say about large power supplies?

Large power supplies (e.g., kicker supplies) need these rules:

(3) Reduce magnetic coupling loops in the high current circuits to the minimum.

(4) Provide a separate return circuit for every voltage source, so that you can:

(5) Ground the system at the best point, often with a soft ground like a resistor.

Figure 5 shows the tunnel of the P-bar source with debuncher ring (left) and accumulator ring (right). The bend and quad magnet circuits (see Table 1) are floating except for the soft grounding via the $10 \mathrm{~K} \Omega$ resistors used in the ground fault protection circuit Leakage currents of more than a few milliamps would compromise the 10ppm magnet regulation and cannot be allowed. As the picture shows, the laminated iron core of each magnet is grounded by a heavy copper wire to a ground bus encircling the rings just below the lowest cable tray of each ring. The stainless steel beam pipe firmly 
contacts the magnet laminations and thus is grounded at each magnet. The copper ground bus on the cable tray connects to an array of ground rods buried in the earth outside the tunnel. Each ring has a D.C. Beam Current Monitor (a second-harmonic magnetic modulator type). It is magnetically shielded by multi-layer Permalloy ${ }^{2}$ pipes.

Figure 6 shows the surface buldings of the P-bar source. Space does not permit a description of the very interesting RF stochastic cooling ring and kicker systems of the P-bar source, but a tribute is in order. No stack of $P$-bars has ever been lost because of thunderstorms ${ }^{3}$.

Figure 7 is a view down in the Main Ring tunnel showing the row of 18 copper accelerating cavities $(53 \mathrm{MHz})$. The three-stage power amplifiers are clamped directly to the cavities by Marman clamps. All power amplifier sections are tin plated for good RF contact. To check the contact after an amplifier is replaced, D.C. current of 100 amps is run from the top of the amplifier down to the cavity and the voltage drop at each clamp joint checked to verify that it is below $50 \mu \mathrm{V} @ 100$ Amps.

Figure 8 shows the top of the $12 \mathrm{MW}, \mathrm{L}-5859805 \mathrm{MHz}$ klystron. There is a stack of 4 circular, lead X-ray shields surrounding the isolated collector and additional lead shielding around the top of the solenoid. Both X-ray levels and RF leakage had to be addressed, because the circular shields act as both X-ray attenuators and as a metallic enclosure to shield collector RF. For improving the RF shielding, it was necessary to remove paint from the contacting surfaces and to apply bolt pressure to force flanges into intimate contact. Figure 24 shows the D. C. current method of testing joint contact resistance, applied to the stack of lead shields.

Figure 9 shows the testing of the WR-975 waveguide joints with a 2point probe. The Tektronix $7104,1 \mathrm{GHz}$ oscilloscope, directly shows the $805 \mathrm{MHz}$ signal if the flange joint is leaky. At $8 \mathrm{MW}$ in the waveguide, every joint exhibits a few millivolts; the test is to see whether a given joint is much leakier than the best joint ${ }^{4}$. If it is, it can be restored by cleaning the flanges, installing a new gasket and retorquing the flange bolts.

One of the most demanding RF installations is the amplifier chain for stochastic cooling, where signals at the shot noise level in the beam are amplified up to watts at the TWT outputs (Figure 10). Even small RF leaks could cause the amplifier chain to become an oscillator. Careful attention is paid to using solid-jacket coaxial cable with good-quality connectors, properly torqued. In some other installations, we have found it best to solder connectors to the copper-jacketed cable (even if the connectors are designed for straight mechanical assembly).

The above experiences suggest another rule:

(6) Have a test plan to determine that the installed shielding actually works as intended. 


\section{DETECTOR SHIELDING EXAMPLES}

Table 2.

\begin{tabular}{|c|c|c|c|c|c|}
\hline DETECTOR & FAEQUENCY & $\begin{array}{l}\text { APPROX. } \\
\text { SIGNAL } \\
\text { LEVELL }\end{array}$ & $\begin{array}{c}\text { MAXIMUM } \\
\text { ALLOWABLE } \\
\text { INTERFER- } \\
\text { ENCE }\end{array}$ & $\begin{array}{l}\text { AMBIENT } \\
\text { STRAYS }\end{array}$ & $\begin{array}{c}\text { MINIMUM } \\
\text { SHIELDING } \\
\text { BELOW } \\
\text { AMBIENT }\end{array}$ \\
\hline $\begin{array}{l}\text { D.C. Beam } \\
\text { Current } \\
\text { Monitor }\end{array}$ & D.C. & $1 \mathrm{~mA}$ & $0.5 \mu \mathrm{A}$ & $\begin{array}{l}10 \text { Gauss... } \\
20 \mathrm{~mA} \text { on } \\
\text { beampipe.. }\end{array}$ & $\begin{array}{l}\ldots .60 \mathrm{~dB} \\
\ldots .92 \mathrm{~dB}\end{array}$ \\
\hline $\begin{array}{l}\text { Beam } \\
\text { Position } \\
\text { Detector }\end{array}$ & $53 \mathrm{MHz}$ & $150 \mu \mathrm{V}$ & $1 \mu \mathrm{V}$ & $1 \mathrm{mV} /$ meter & $60 \mathrm{~dB}$ \\
\hline $\begin{array}{c}\text { Cavity } \\
\text { Phase and } \\
\text { Amplitude } \\
\text { loops }\end{array}$ & $805 \mathrm{MHz}$ & 1 Volt & $0.5 \mathrm{mV}$ & $\begin{array}{l}20 \mathrm{mV} / \\
\text { meter }\end{array}$ & $32 \mathrm{~dB}$ \\
\hline $\begin{array}{l}\text { Modulator } \\
\text { Regulation } \\
\text { Loop }\end{array}$ & $\begin{array}{l}125 \mu \mathrm{sec} \\
\text { pulse, } \\
15 p p s\end{array}$ & 10 Volts & $1 \mathrm{mV}$ & $\begin{array}{c}2 \text { Volts } \\
\text { between } \\
\text { widely- } \\
\text { separated } \\
\text { racks }\end{array}$ & $66 \mathrm{~dB}$ \\
\hline
\end{tabular}

If the EMI generators of Table 1 are shielded carefully, the ambient noise can be reduced to that of column 5 above. I would consider the levels of column 5 to be a reasonably livable electrical environment. Then, the request to the group designing high-power equipment would be "Shield well enough to meet column 5". The request to the detector people would be, "Shield well enough to live with column 5 ".

Take a particular case, the $12 \mathrm{MW}$ klystron of Table 1 . To reduce 12 $\mathrm{MW}$ to $20 \mathrm{mV} / \mathrm{meter}$ ambient requires $\sim 131 \mathrm{~dB}$ of shielding. To reduce 20 $\mathrm{mV} /$ meter to $0.5 \mathrm{mV}$ requires only $32 \mathrm{~dB}$.

It may seem unfair to make the high-power people work harder than the low-level group but it may turn out that way. Keiser ${ }^{5}$ discusses "Principles of Electromagnetic Compatibility" in a general context.

\section{SOME TOOLS FOR SHIELDING TESTS}

Figure 11 shows some tools for shielding tests. The current transformer ${ }^{6}$ on the left has a $3 \mathrm{~dB}$ passband from $23 \mathrm{~Hz}$ to $180 \mathrm{KHz}$. It is used to check for current where there should be none (we always find some). Next to it is the Tesla coil, or "cattle prod". The Tesla coil generates $\sim 50 \mathrm{KV}$ at its tip. If the tip is not close to another conductor, there is air corona at the tip; the corona spikes form a handy, controllable, radiated, wideband source ${ }^{7}$ good from $100 \mathrm{KHz}$ to $\sim 4 \mathrm{GHz}$ (If the tip is close-sparked to another 
conductor, the spectrum widens to $22 \mathrm{GHz}$ ). The Tesla coil is excellent for testing the shielding of certain critical TTL and ECL logic circuits where the error rate must be very small to avoid expensive nuisance trips.

The next item shown is a short dipole antenna formed by stripping back a length of copper-jacketed coax. It is used for hunting corona in high voltage apparatus. A hot-carrier diode detector with 10 millisecond decay time is convenient for scope observation of corona. A second use for the antenna is to radiate RF to test shielding. It is then called an "RF sprinkler". We expect rack instrumentation to work in RF fields up to several V/meter; the RF sprinkler helps verify this. The last thing shown is the 2-point probe that appeared in figure 9, measuring $805 \mathrm{MHz}$ signals across waveguide flanges. The 2 points are very directly connected to a $1 / 4$ " diameter solidjacket $50 \Omega$ coaxial cable.

Figure 12 shows the current transformer in use. We found an unwanted external current of $\sim 6$ amps peak, shaped like the $125 \mu \mathrm{sec}$ modulator pulse. It was narrowed down to a particular cable. Then it was clear where to add filtering to reduce the stray current to a few milliamps.

Figure 13 is a typical rack installation. Note the ground wire connected to each rack top. Note also that the shields of all cables are coaxially grounded at the rack top, as is also shown in Figure 17. Sometimes adjacent rack tops are joined by full-width, 10-mil copper jumpers, to create a ground plane.

Flgure 14 shows copper water pipe in use as a conduit (shield) for the primary 117 V.A.C. to the Sola transformer located inside the rack. Power line spikes and RF were prevented from coupling into the rack interior volume. The rack becomes a first-stage shield. Later, we say more about staging.

Figure 15 shows an earth ground conductor running to a steel building column. It is common to measure milliamps to amps fluctuating currents of 60 and $180 \mathrm{~Hz}$ A.C. on these conductors.

Figure 16 shows an assortment of ferrite and Permalloy tapewound cores for raising the external impedance of cables, thus reducing coupled noise. Increasing the external impedance lowers the external currents that arise both from B-dot and from source to destination ground voltage differences. Remember that the impedance added to the cable external current path is proportional to the number of turns squared. The larger tapewound cores are often used with several turns of coax through them.

Figure 17 shows a bundle of $1 / 2$ " solid-jacket $50 \Omega$ coaxes, each cable surrounded by a packet of 10 ferrite cores. The cores act as terminations $(\sim 100 \Omega$ resistive) to the external RF on the copper cable jacket. Without the cores, there would be current maxima just at the rack top, hence greater coupling of external noise into the signal. We also use these cores as local "noise current" transformers by slipping a turn of wire through them, parallel to the cable, observing via oscilloscope.

Figure 18 shows the vertical omnidirectional antenna for constantly monitoring RF leakage. The klystron drive is inhibited if RF leakage exceeds the set threshold of $\sim 50 \mathrm{mV} /$ meter. RF leakage is undesireable for 
many reasons. It can cause offsets in operational amplifiers, aliasing in digital sampling scopes and, in larger doses, is potentially hazardous ${ }^{8}$.

Figure 19 shows an RF-tight, see-through screen surrounding the $\mathrm{X}$-ray radiation meter. It was observed that very small amounts of $R F$ invalidated the X-ray measurements. The screen was separately tested by beaming RF at it from the horn antenna; it passed the test (as you would have expected).

Figure 20 shows the horn antenna beaming short bursts of RF at the racks. Some of the rack-mounted equipment did not pass the test. There followed a session of removing paint from old panel backs, grounding metal pot shafts and enclosing rack space with blank panels to cover up holes to get the required shielding.

All the racks have power line filters where A.C. comes in at the rack top. All rack top panels are tin-plated copper, bolted to a tin-plated border at the rack top.

Commercially-made, rack-mounted equipment nearly always has painted panels that do not contact the rack adequately as furnished. We have come to expect we will have to improve the contact ourselves.

Figure 21 shows the copper panels installed in one special rack to make it electrically tighter for its low-level analogue circuitry, controlling the 24MW modulator.

Flgure 22 is a view of racks in the control room Main Ring RF building. Note the blue-painted copper pipes. These pipes carry patch panel cables to the north, east, south and west sides of the control room.

Figure 23 is a close-up of the pipes entering the rack top, which is a tinplated copper plate attached to a tin-plated border on the rack top.

Figure 24 shows the D.C. current scheme in use to identify and pinpoint poor connections, which, in this case, caused RF leaks from the klystron collector of Figure 8. The bottom ring-to-polepiece connection was the poorest, followed by the top plate. Both connections were later improved.

Figures 25 and 26 show internal shields placed in a NIM plug-in to protect the 9685 comparator from false triggering. In this case, a spurious pulse would shut down the accelerator. To avoid nuisance trips, the shielding was added and bench-tested, up to nuclear electromagnetic pulse, or NEMP, levels; $50 \mathrm{KV} / \mathrm{meter}$ and 5 nsec rise time.

Figure 27 shows active noise reduction. The noise voltage difference at power line frequencies and magnet cycling rate between the tunnel ground (i. e., beam pipe) and the rack ground was a problem. In order to complete a run in timely fashion, the circuit shown was assembled. It succeeded in reducing the noise by $\sim 50 \mathrm{~dB}$ from $3 \mathrm{~Hz}$ to $1 \mathrm{KHz}$. A completely passive circuit with a huge core would do a similar thing. Even better would be a detector (or rack receiver) that would eliminate the need for a ground at both ends (we had neglected to follow our own Rule no. 2).

It is helpful to design tunnel mounted detectors so they are electrically isolated from the beam pipe. Then, a metal box surrounding the detector is required, of sufficient wall thickness to provide eddy-current shielding; this box must join the upstream and downstream ends of the beam pipe so that external currents on the beam pipe flow over the box exterior (a Gaussian enclosure). 
Figure 28 is a tuned, stripline beam position detector. The external beam lines use a number of these; the $53 \mathrm{MHz}$ bunch structure of the beam generates the position signal. Because some beams are low current, the circuitry must be free of interference at even the microvolt level. An unexpected case of insufficient metal thickness in a shield provides the next example.

\section{SKIN DEPTH EXAMPLES}

Figure 29 shows stripline beam position detectors in the beam line, underground at the NØ1 service building.

It was found that there was crosstalk between the detectors in the upper beam and the lower beam. The culprit proved to be a 4-mil Titanium window at the end of the detector, leaking RF because it was too thin-only about 2 skin depths. The solution, shown in Figure 30, was to add a 10-mil sheet of copper to supplement the Titanium. This situation is a corollary to experience with the main ring. The stainless steel beam pipe is not sufficiently thick to exclude all leakage due to wall currents of the beam. Anywhere around the ring, in service buildings, signals of $10-50 \mu \mathrm{V} /$ meter can be detected and deciphered to show the circulating beam structure. That this is due to beam and not stray RF is shown by shutting off beam and leaving the RF on; the signal goes away.

\section{SUCCESSIVE LAYERS OF SHIELDING AT INSTRUMENTATION RACKS}

Standard packaging items can stack up to provide effective shielding. Instrumentation racks, bonded together to form a ground plane at the top as described, are the first layer of shielding. Now the internal volume of the rack has a lower ambient noise level than the outside. Like the onion, more layers follow.

The second layer is the crate, bin or instrument case, with its front panel fully contacting the tin-plated rack frame. A third layer is the plug-in module per se. There may be a fourth layer, a separate full-metal enclosure on the printed circuit board of the module. Walker ${ }^{9}$ discusses crosstalk on the board itself.

Power supply wires from one layer to the next are low-pass filtered. Signals are carried from one layer to the next on coax with external ferrite cores. The net effect on noise is that of a ladder attenuator. The rule to make this work is: onion).

(7) Bring all signals in and out of the rack top (the outermost layer of the

\section{A TECHNIQUE TO IMPROVE S/N RATIO}

Figure 31 is a view of the massive liquid argon calorimeter at $D \varnothing$, to be put in the Tevatron colliding beam in 1992. The shielding for the 55,000 twisted-pair signal wires, some of them shown in Figure 32, forms a total 
system enclosure. Figure 33 is a typical copper duct. Multiply shielded, 150 KVA power transformers feed A.C. power to the platform and three floorlevels of equipment. The grounding of the entire system will be chosen for optimum noise rejection.

Besides careful shielding and grounding, baseline subtraction ${ }^{10}$ helps to produce accurate signals. Baseline subtraction here depends on knowing the crossing time of $\mathrm{P}$ and $\mathrm{P}$-bar bunches inside the detector (known from RF bucket timing). The signal amplifier's output is sampled and held separately two times, once just before crossing and again just after crossing. A digitized difference is taken to be the true signal, free of drift and low-frequency noise.

Does shielding have a future? Yes, see Figure 34-the next Fermilab project!

\section{ACKNOWLEDGEMENT}

I would like to thank Paul L. Cliff of Fermilab for expert help in assembling this report. 


\section{BJBLIOGRAPHY AND NOTES}

1. Private communication, from Scott MIller, SSC Timing Section Head, and Sam Crivello, SSC Fiber Group. Fiber optics are cost-effective. Singlemode fibers with pure silica cores are the choice for the $87 \mathrm{Km}$ runs around the Collider, and shorter runs for the HEB, MEB and LEB rings. Radiation effects on fibers and optimum topologies are under study.

2. The name 'Permalloy' was given to the high permeability iron-nickel alloys for low magnetizing forces by Bell Telephone Laboratories. See G. W. Elmen, "Magnetic Alloys of Iron, Nickel and Cobalt", Journal of Franklin Institute, Vol. 207, May, 1929, No. 5. We used 4.75-80 Permalloy; it is marketed under numerous trade names and can be formed, TIG welded and annealed for D.C. $\mu>50,000$.

3. Private communication, Robert Oberholtzer, Fermilab.

4. Aluminum alloy waveguide needs a coating; Spec. MIL-C-5541D Class 3 chromate conversion coating gives suitable electrical contact.

5. Bernhard E. Keiser, "Principles of Electromagnetic Compatibility", 3rd Edition, Artech House, 685 Canton Street, Norwood, MA 02062.

6. AEMC Corporation, Model SD603. We fitted it with a coaxial output cable to a terminated $50 \Omega$ scope input.

7. The Tesla coil is a portable impulse generator, handy for comparative tests. Indoors, at distances between 1 foot and 40 feet, the signal can be set by distance over a $60 \mathrm{~dB}$ range.

8. See IEEE Publications C95.1 (1991) "Standard Safety Levels with respect to Human Exposure to RF, Electromagnetic Fields, $3 \mathrm{KHz}$ to 300 $\mathrm{GHz}$ " and C95.3, "Recommended Practice for the Measurement of Potentially Hazardous E.M. Fields for RF and Microwaves", avaialable from:

\section{IEEE Service Center}

P. O. Box 1331

Piscataway, NJ 08855

9. Charles S. Walker, "Capacitance, Inductance and Crosstalk Analysis", (1990), Artech House ibid.

10. Private communication, George Krafczyk, Fermilab. 


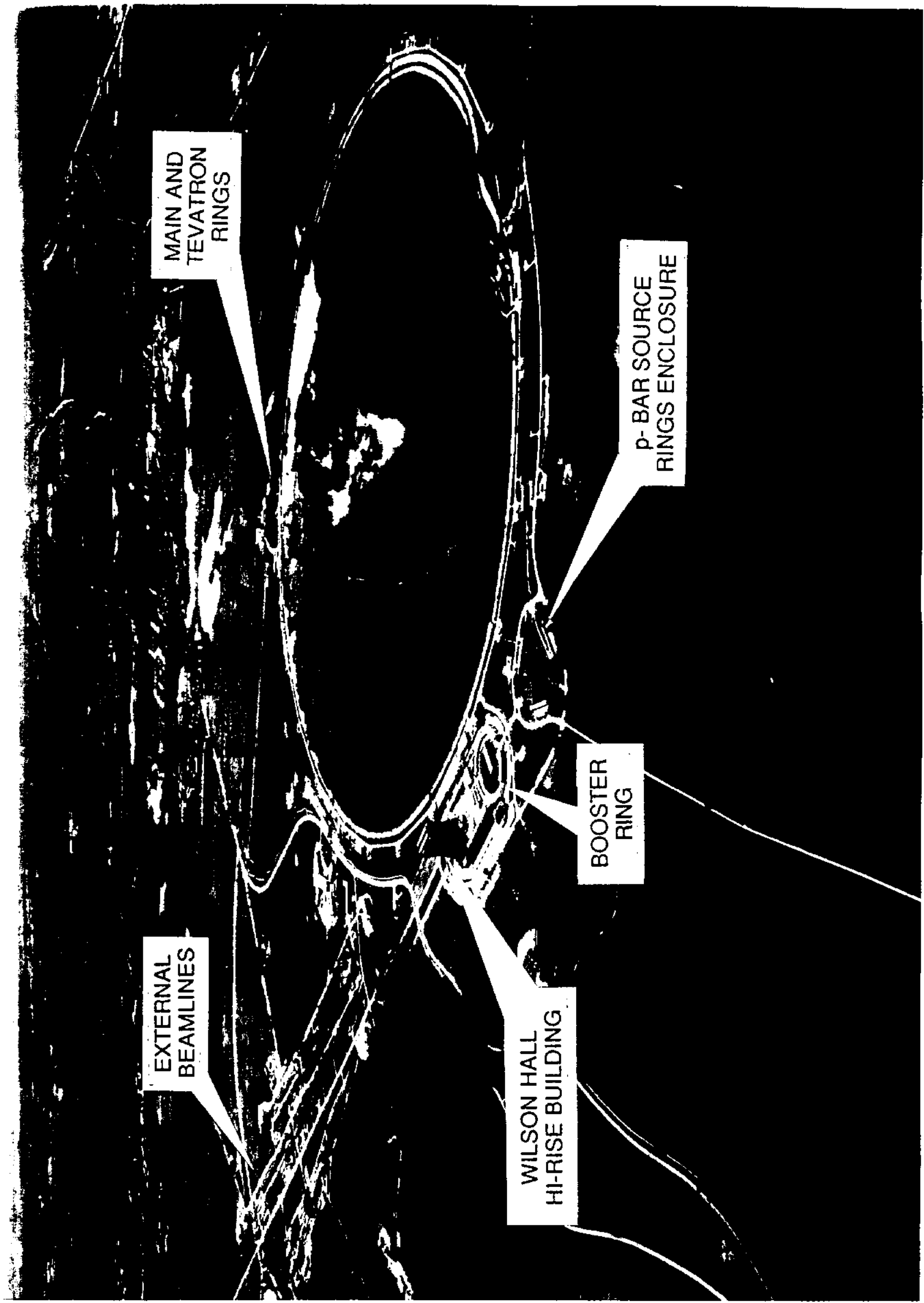

Figure 1. 


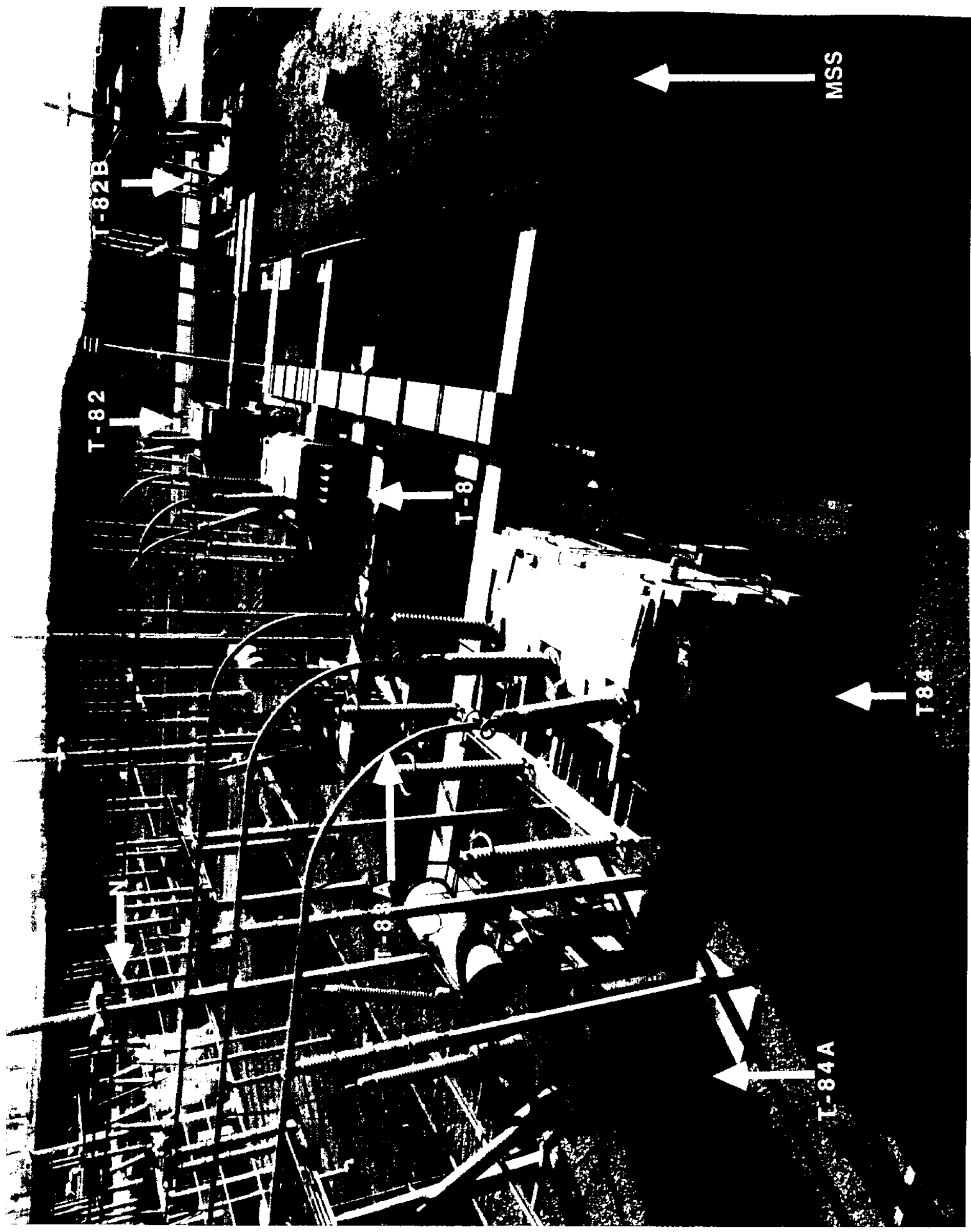

Figure 2. 


\section{TYPICAL ACCELERATOR ENVIRONMENT}

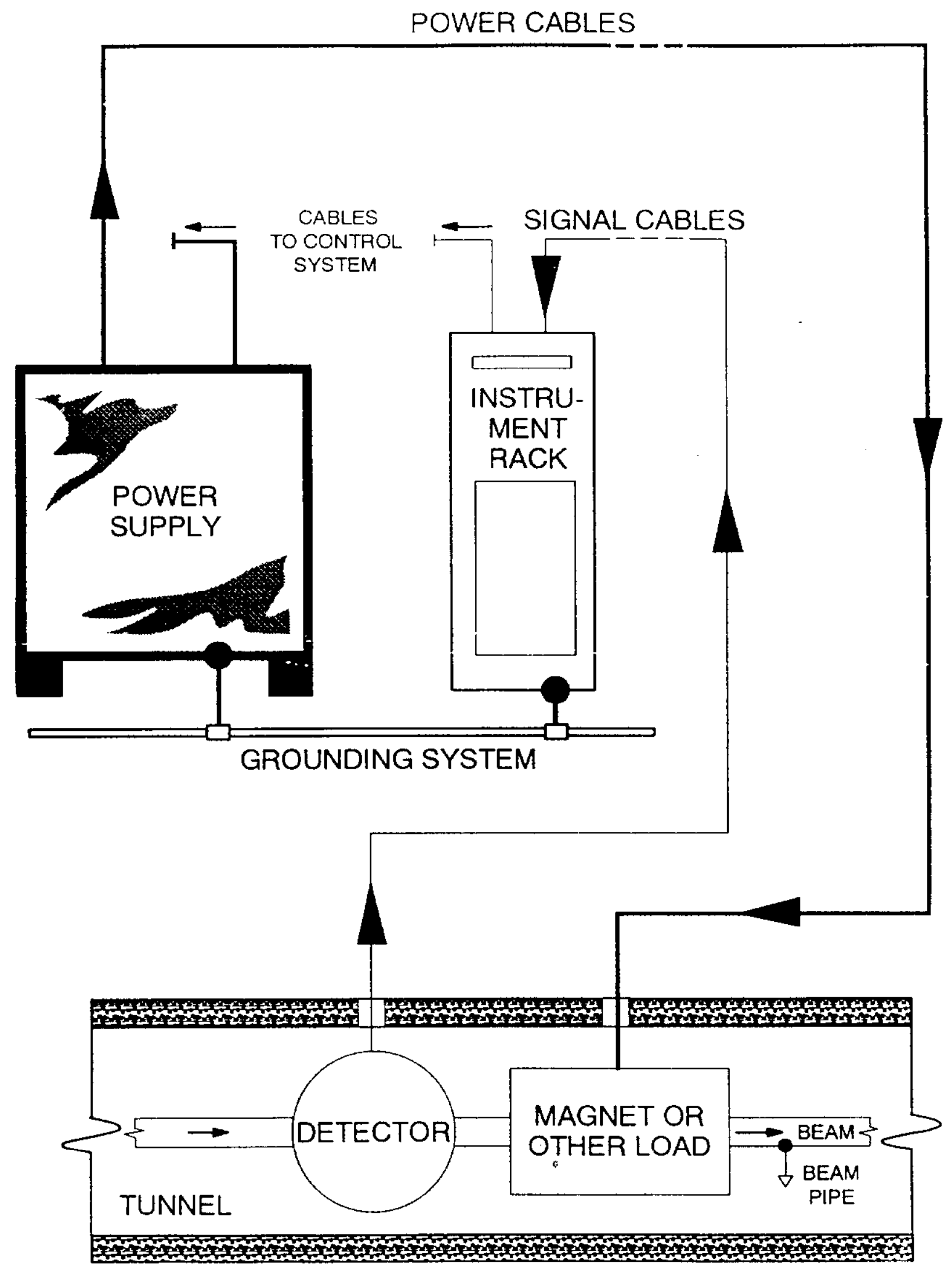

Figure 3. 


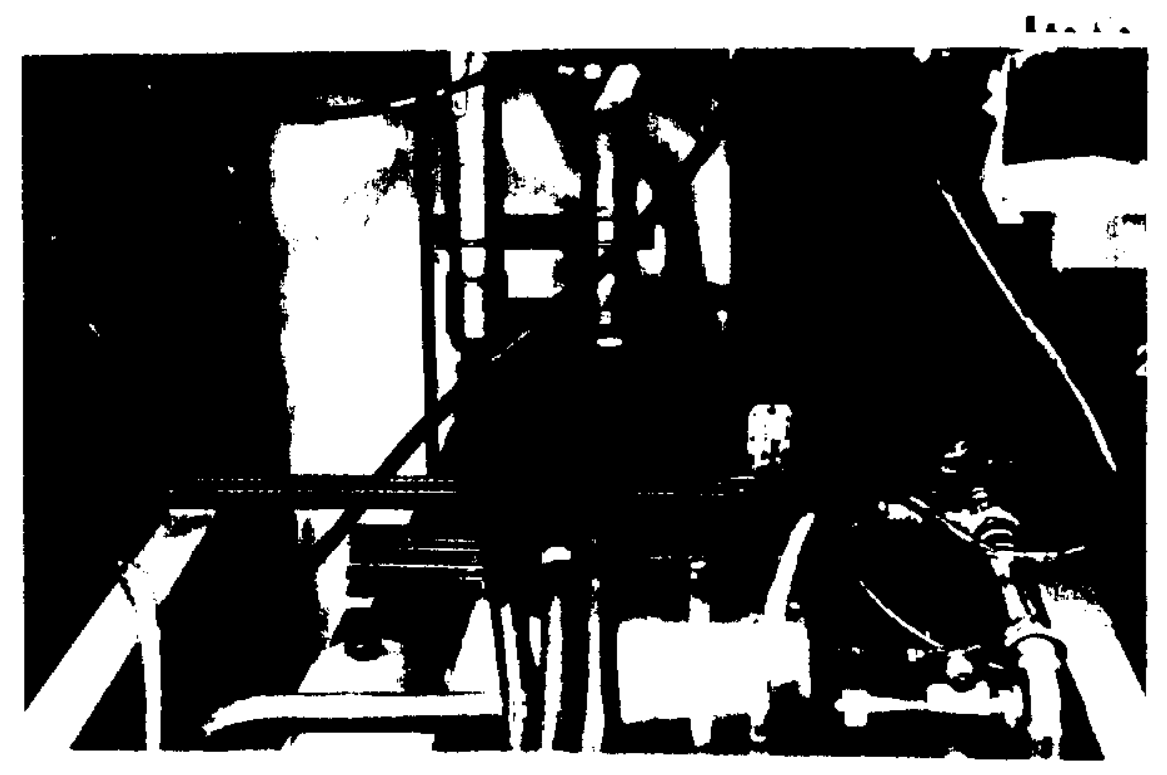

Figure 4

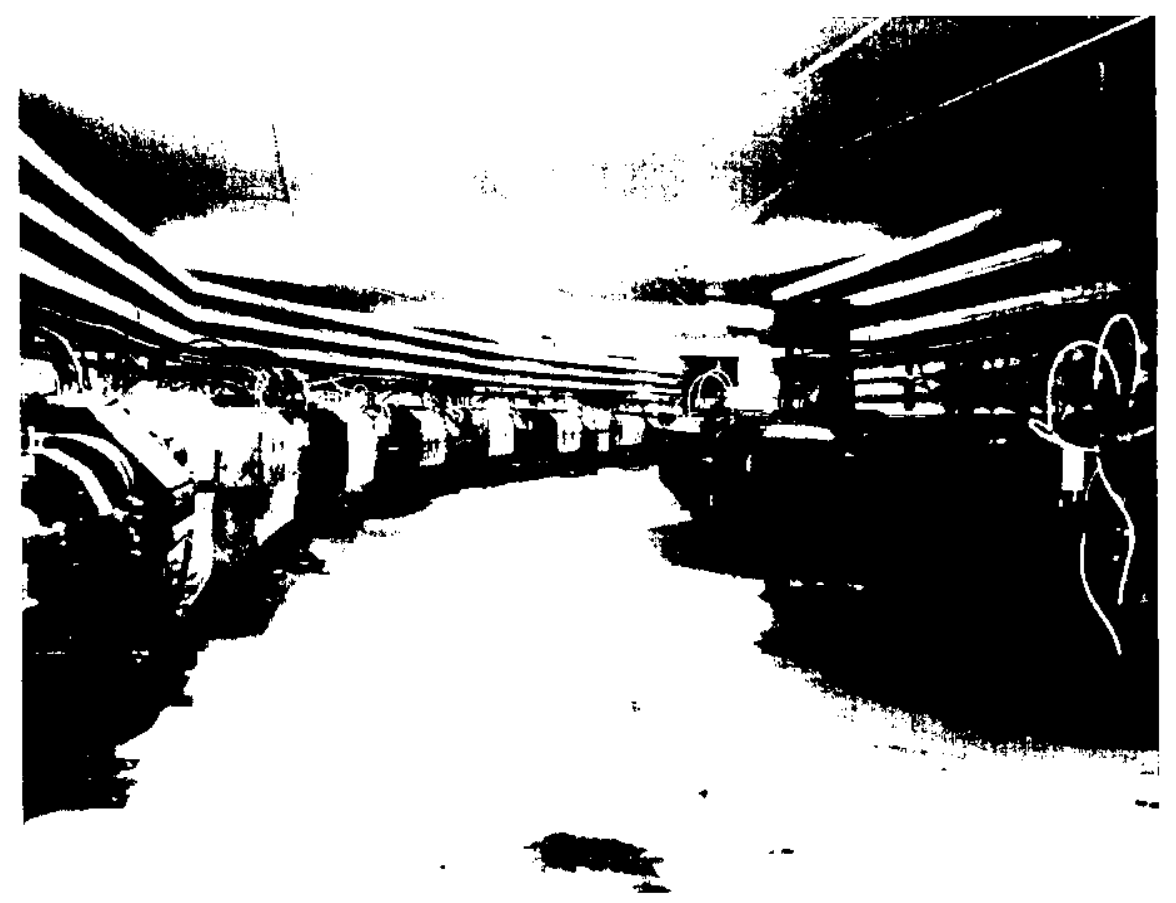

Figure 5 . 


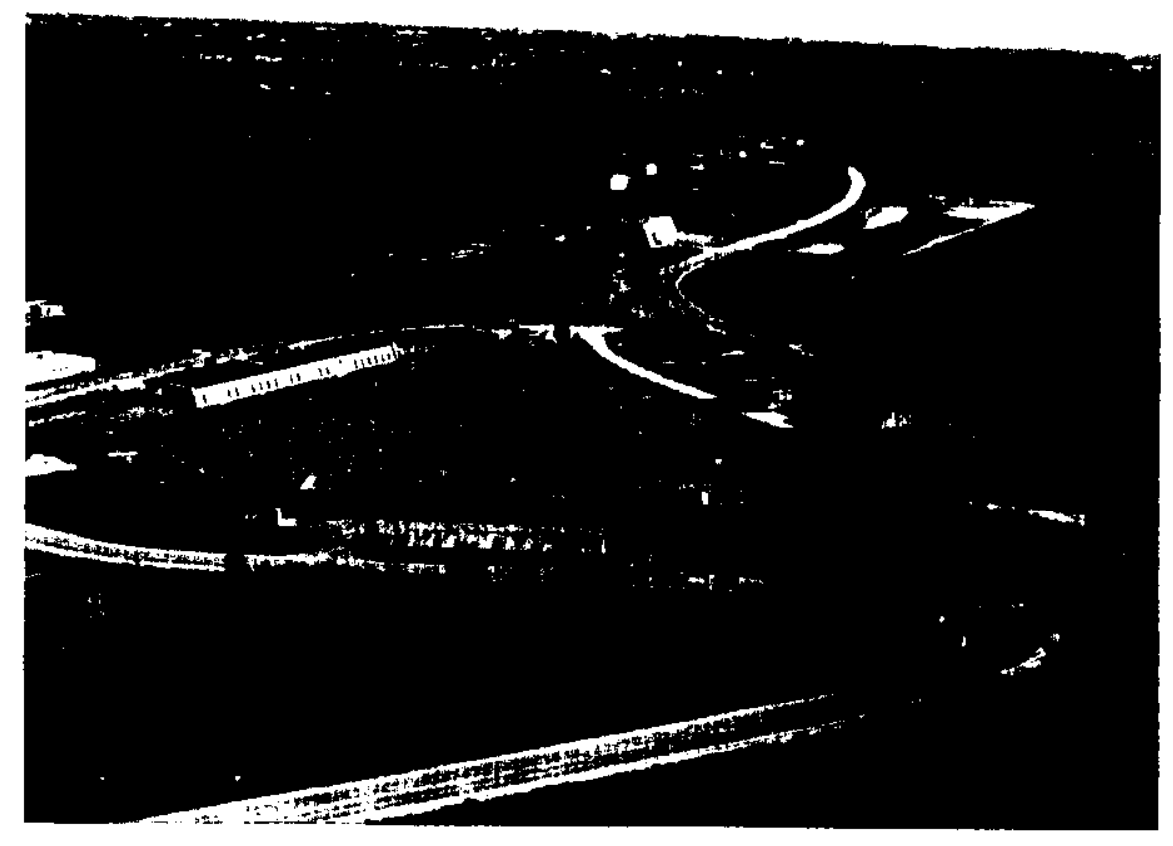

Figure 6.

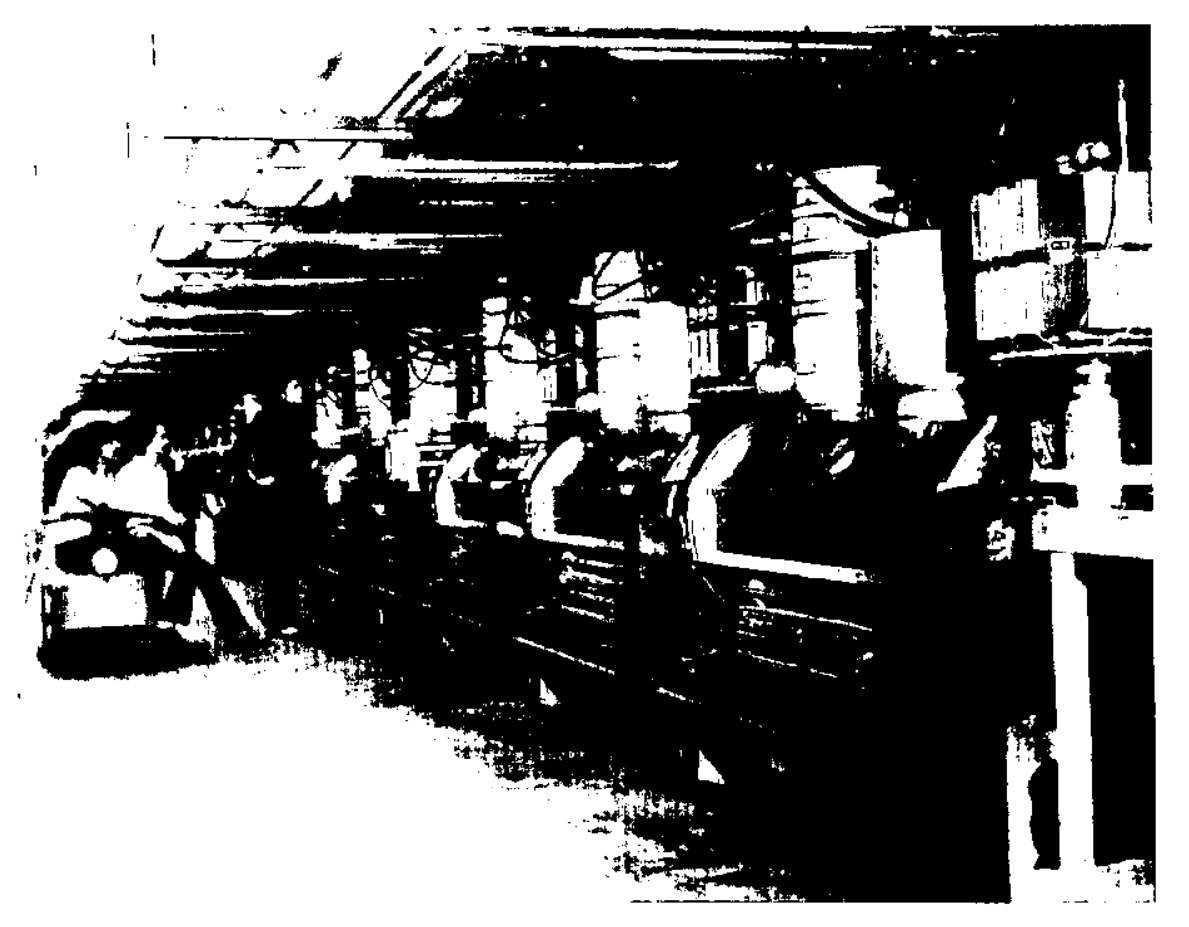

Figure 7. 


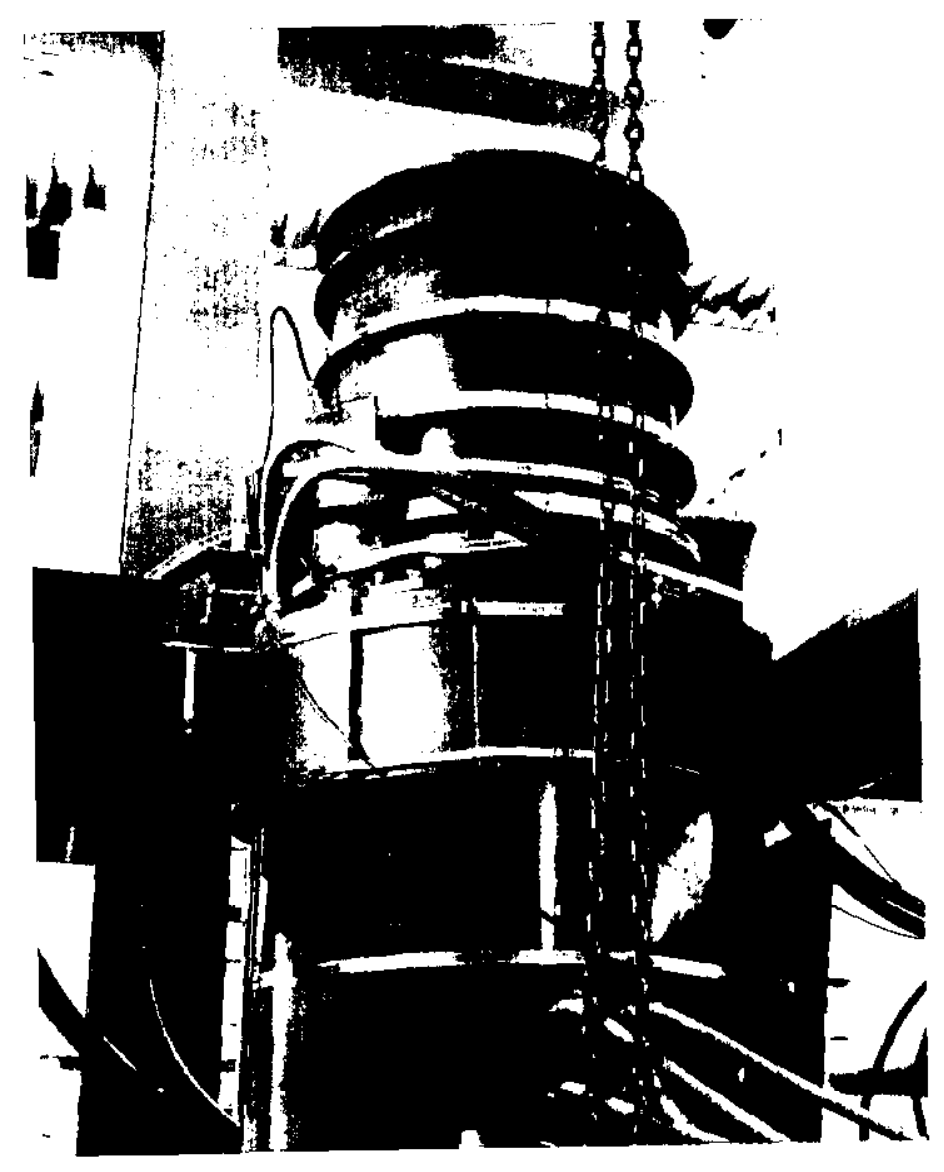

Figure 8. 


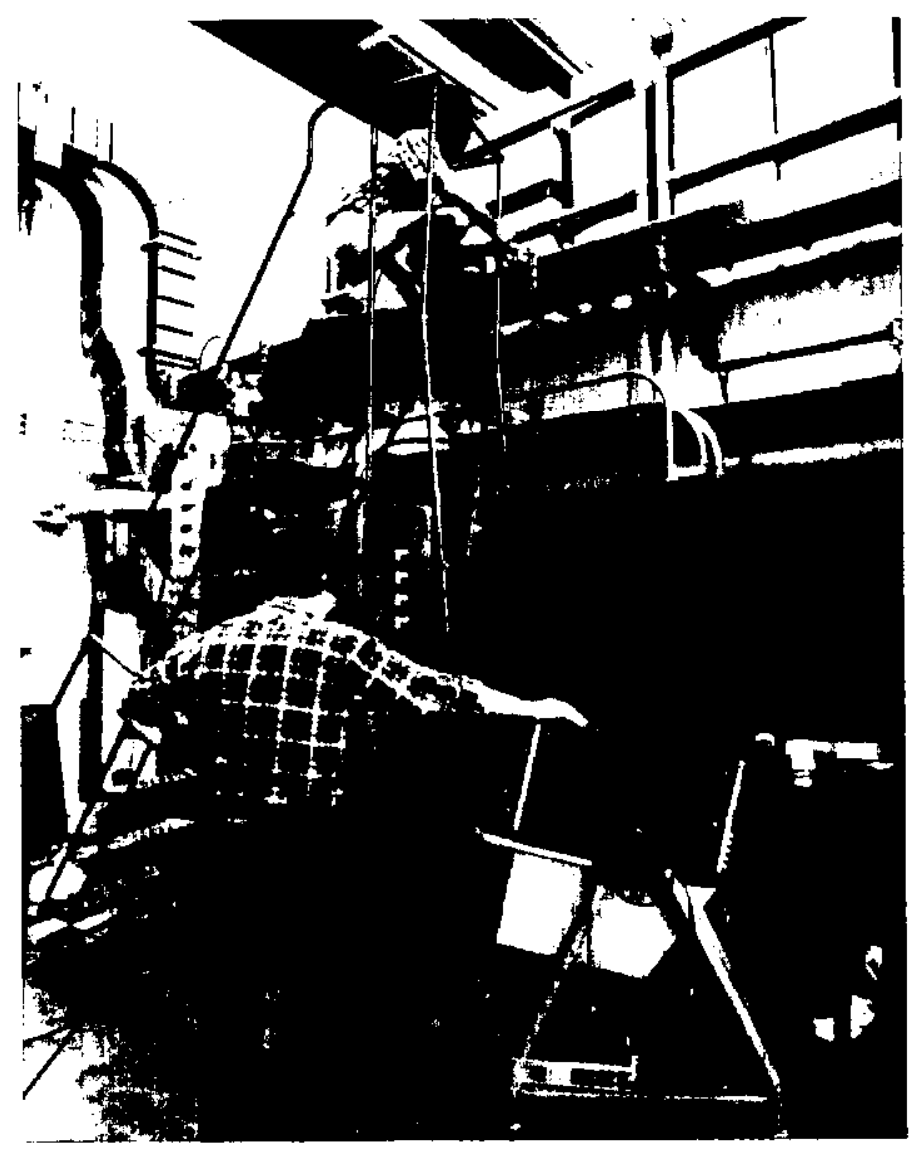

Figure 9. 


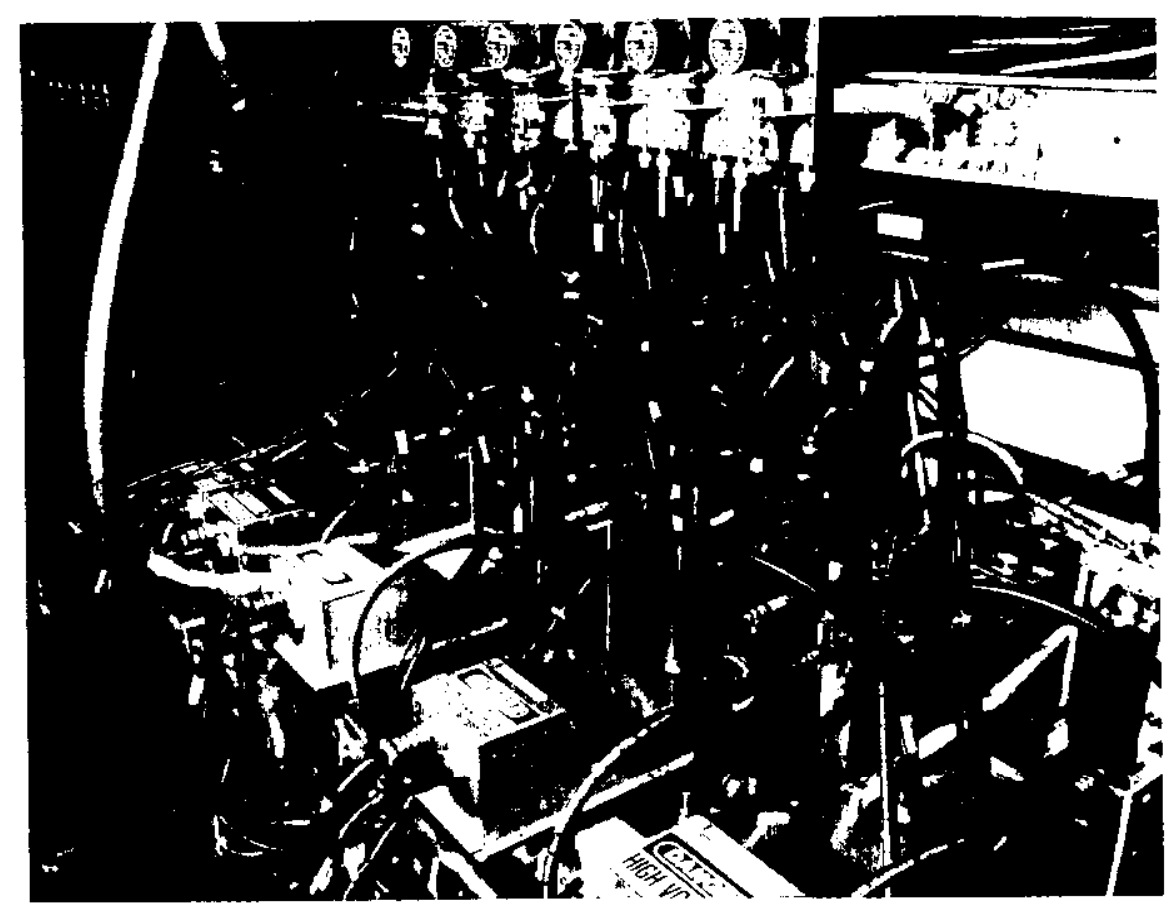

Figure 10.

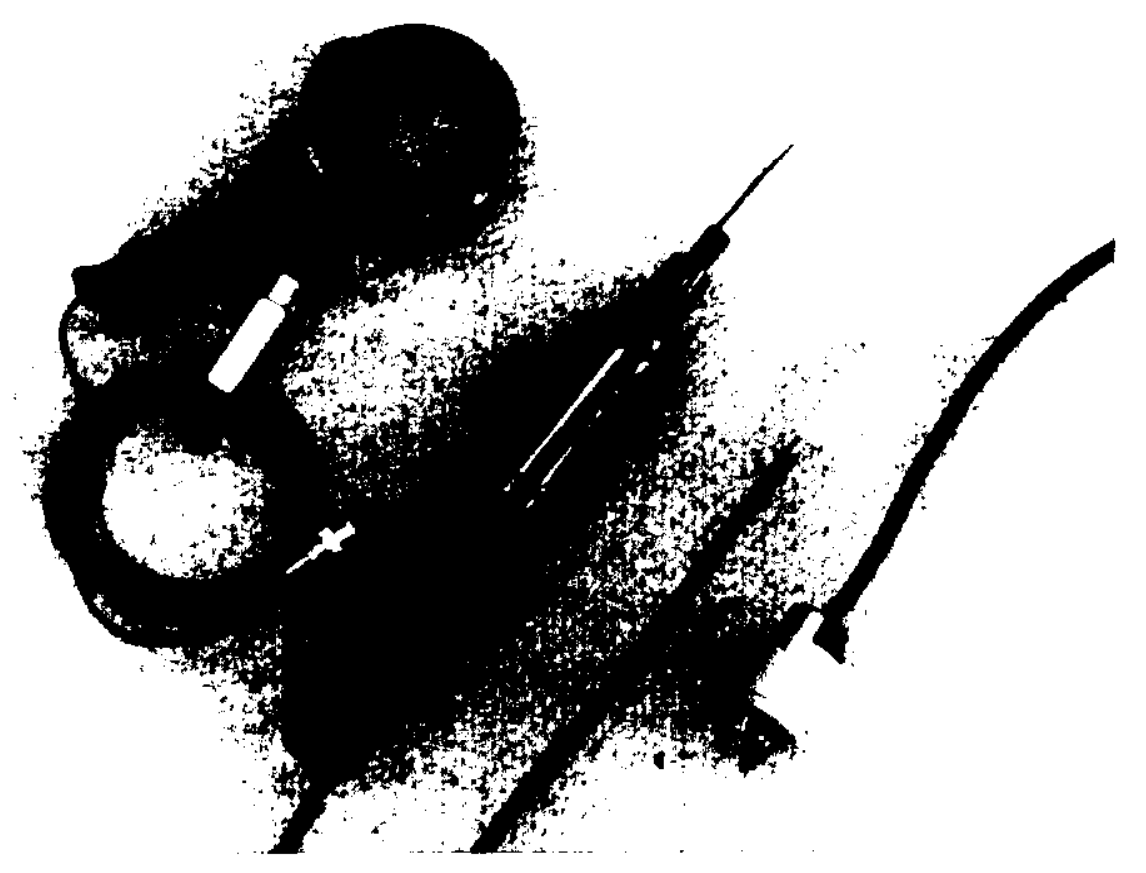

Figure 11. 


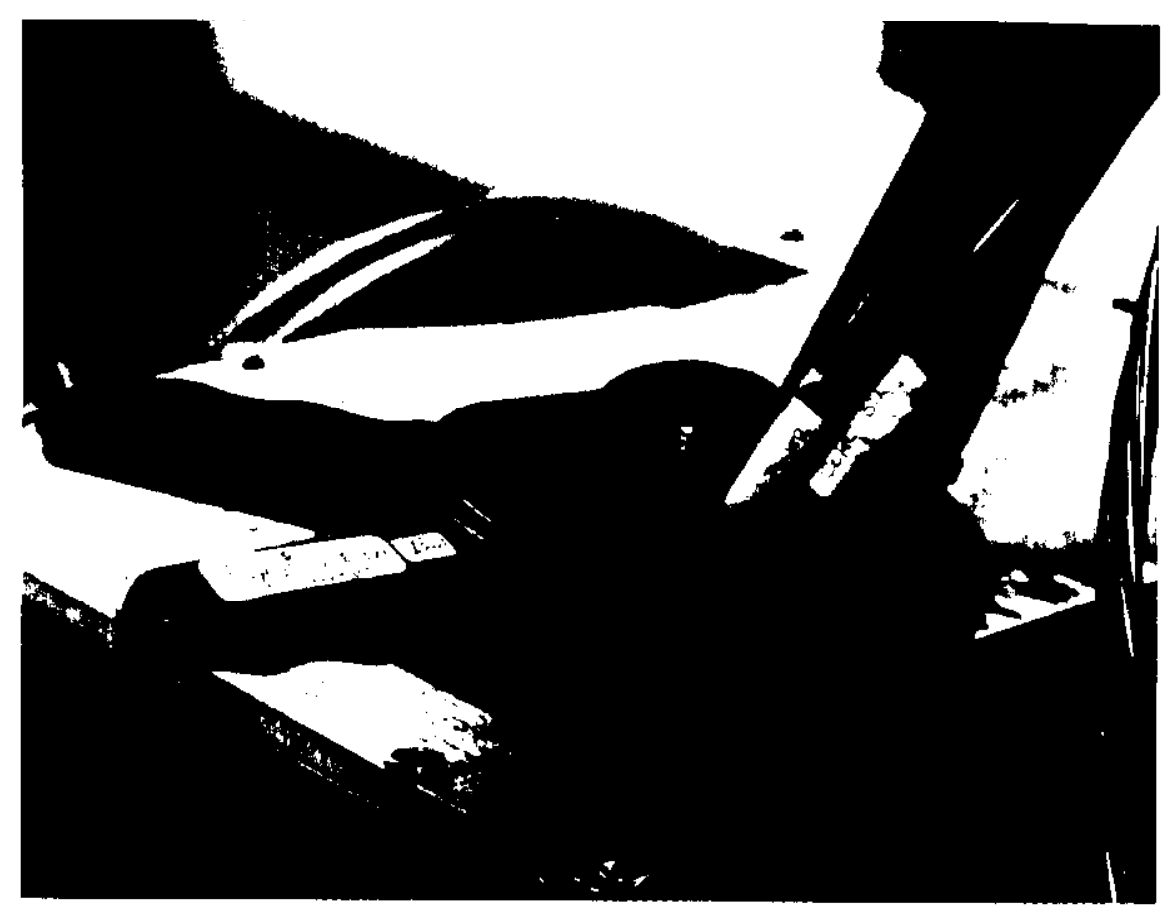

Figure 12.

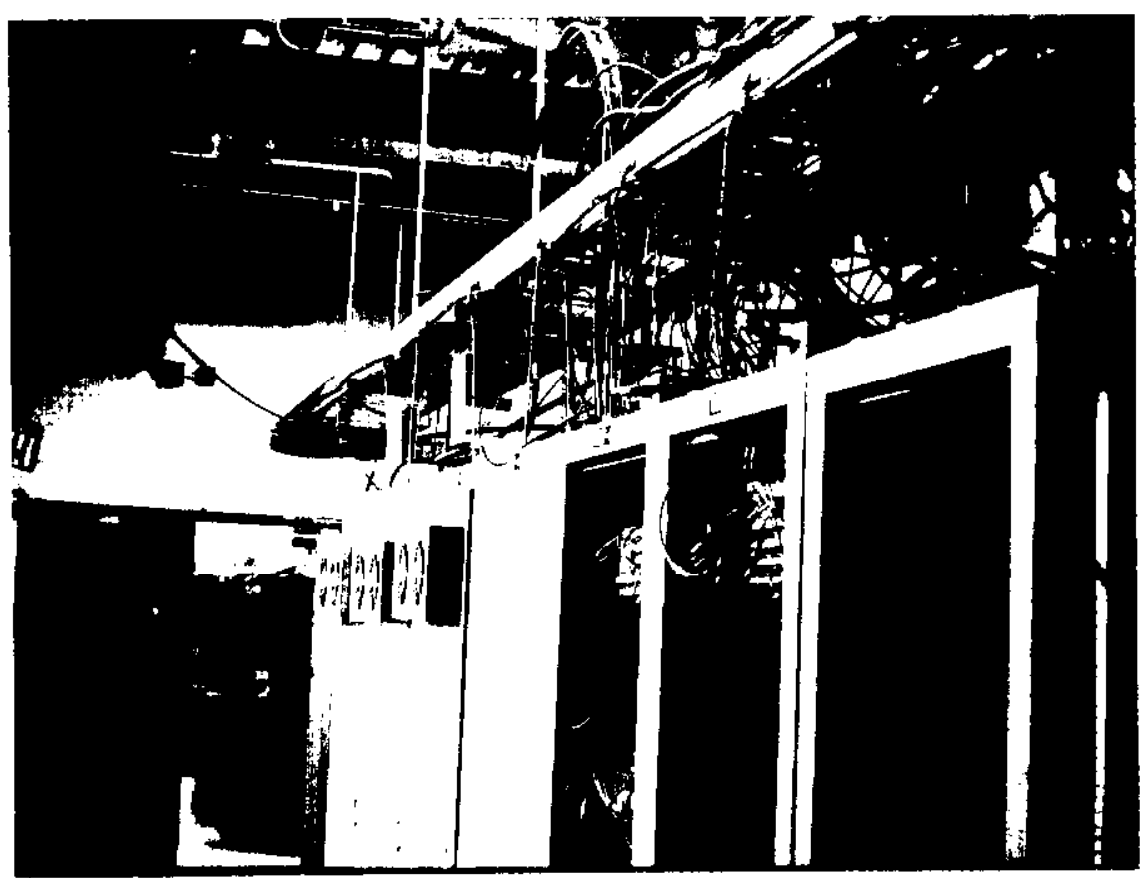

Figure 13. 


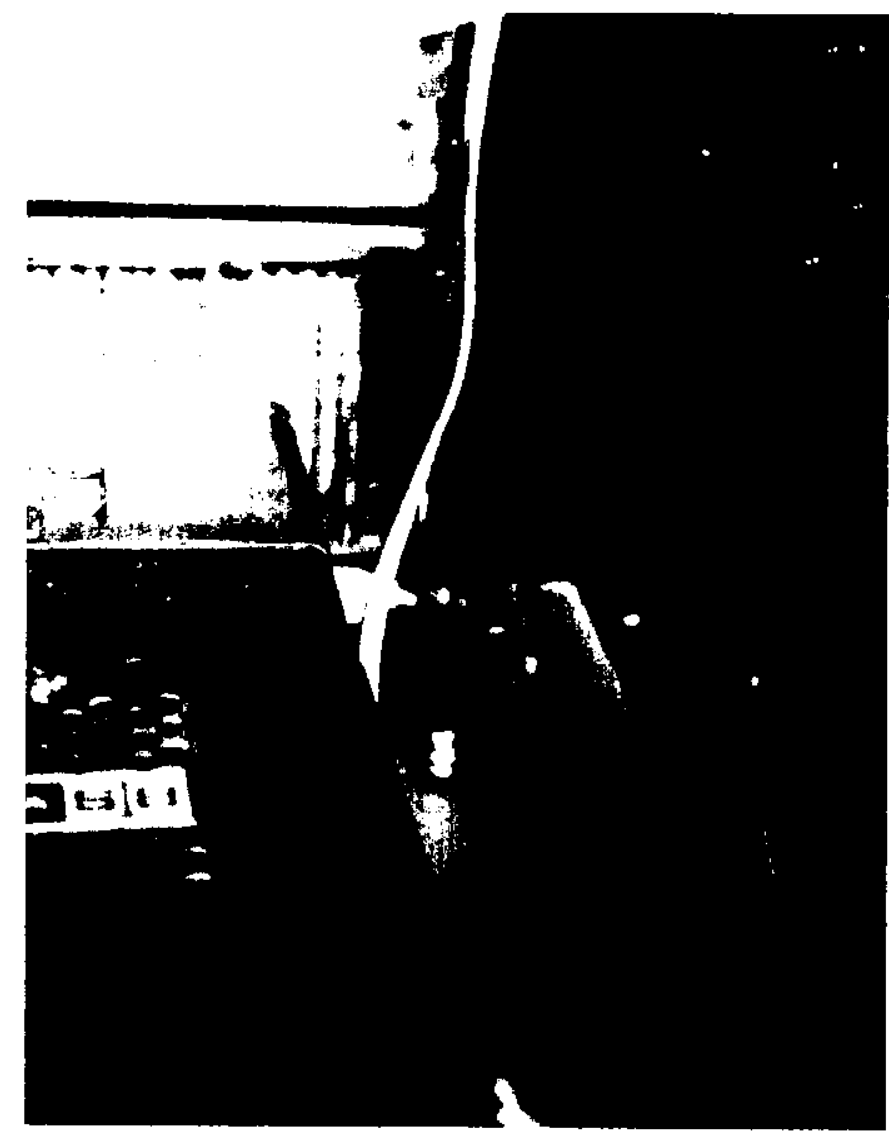

Figure 14. 


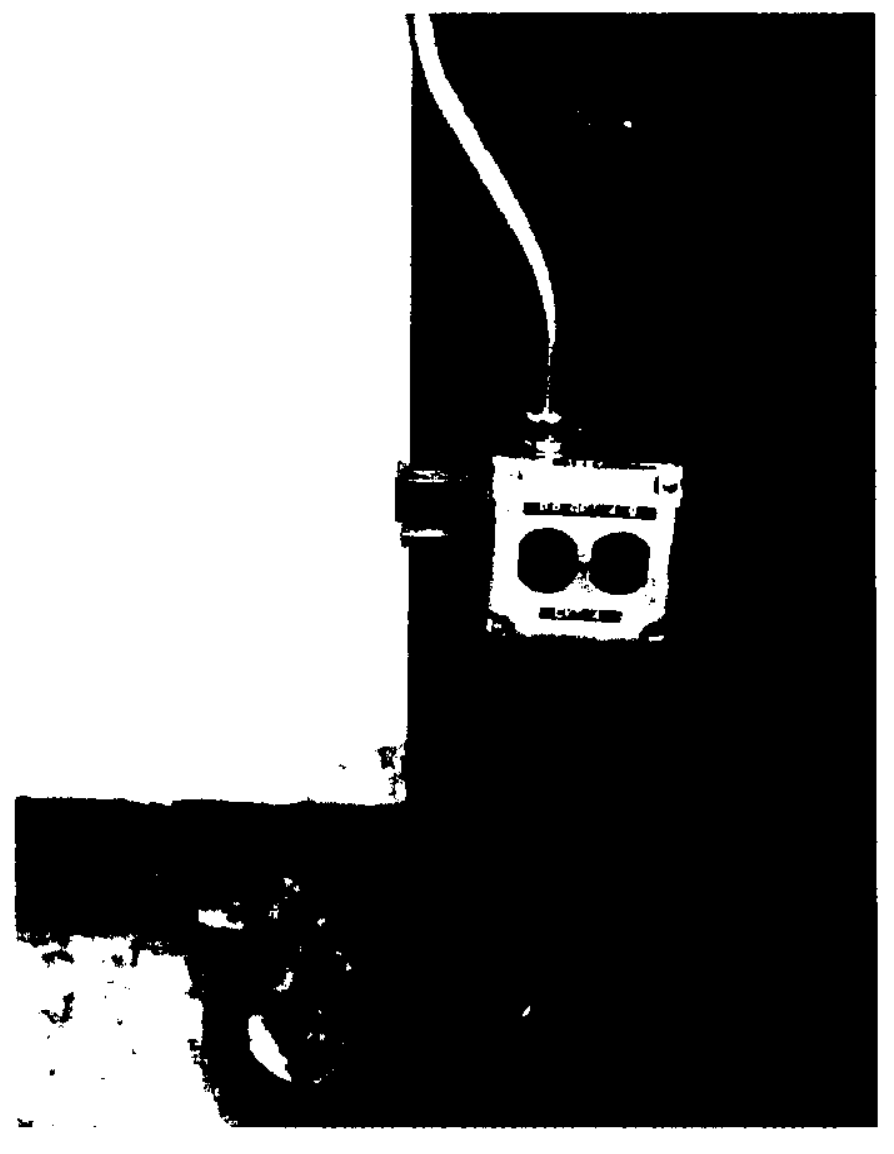

Figure 15 


\section{RFI SUPPRESSION}
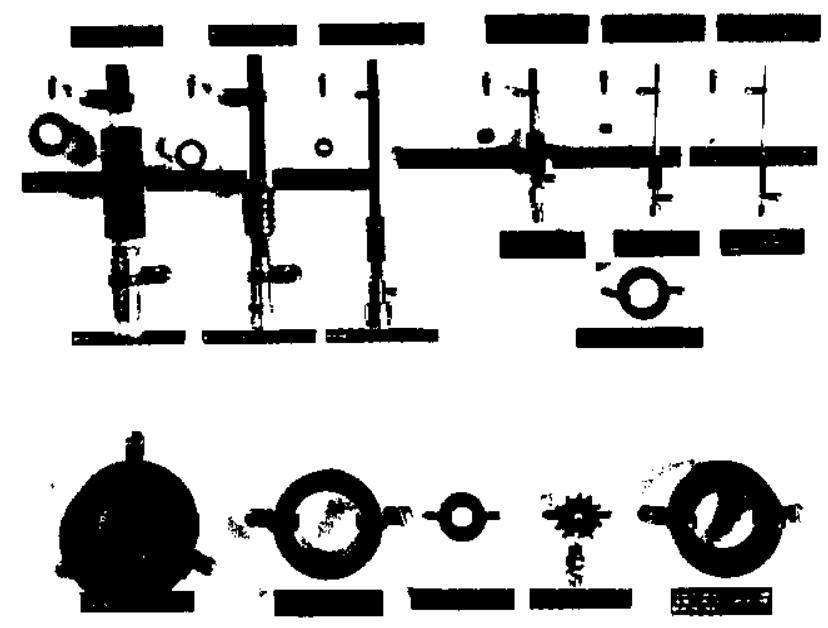

Figure 16. 


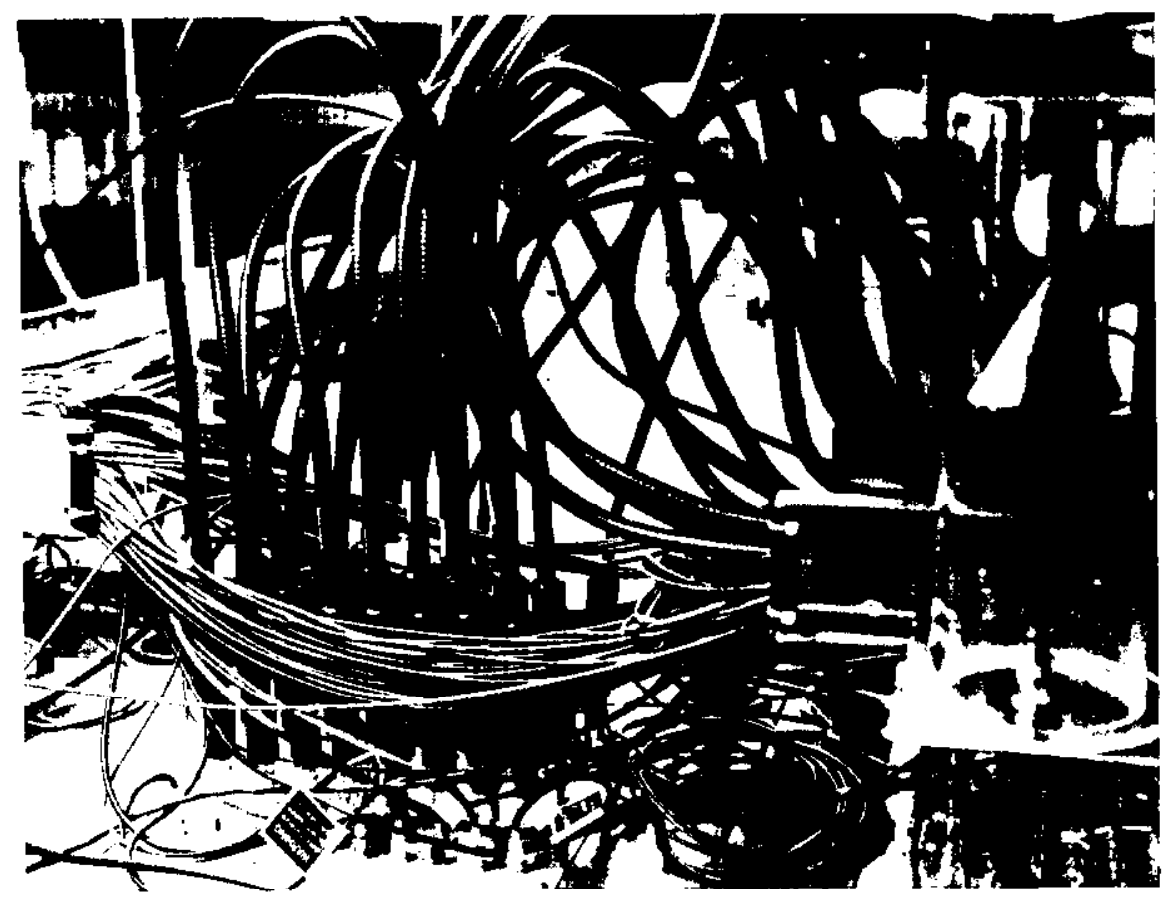

Figure 17. 


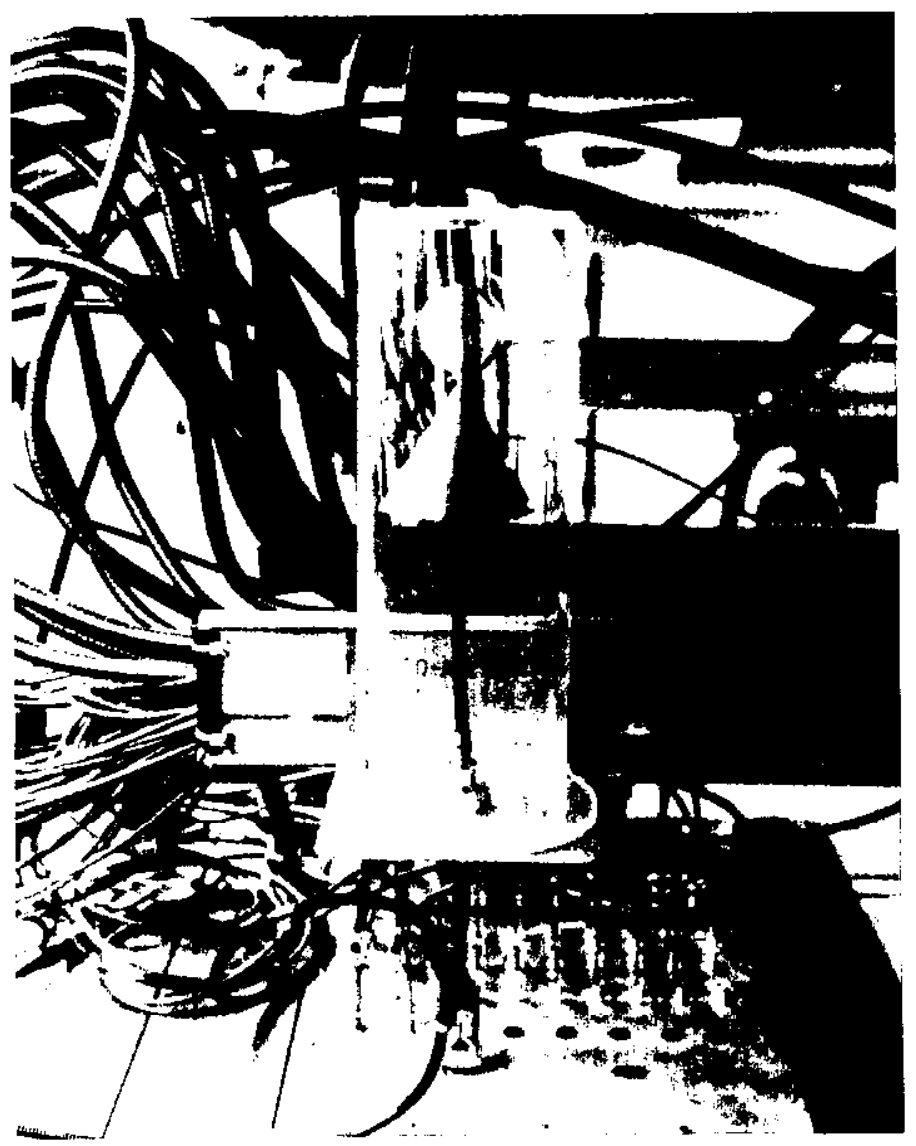

Figure 18. 


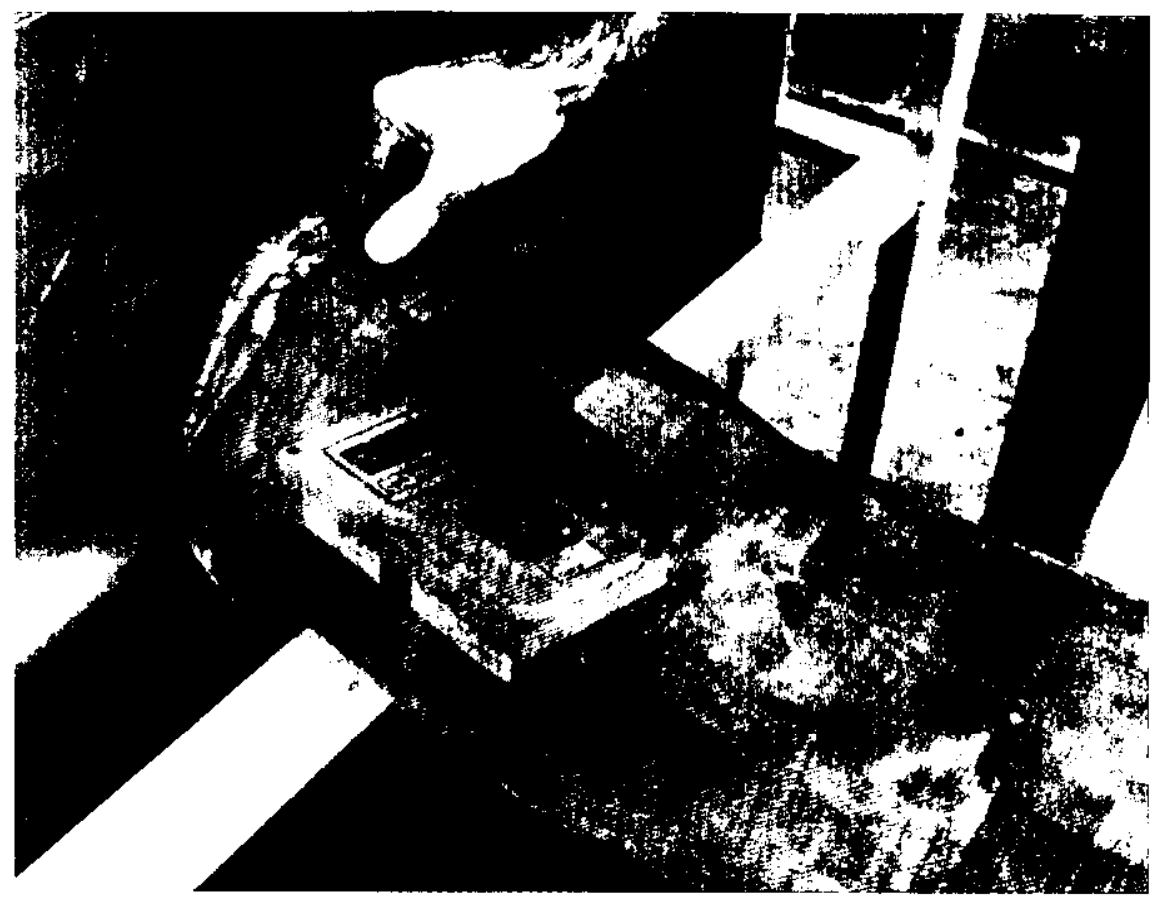

Figure 19 


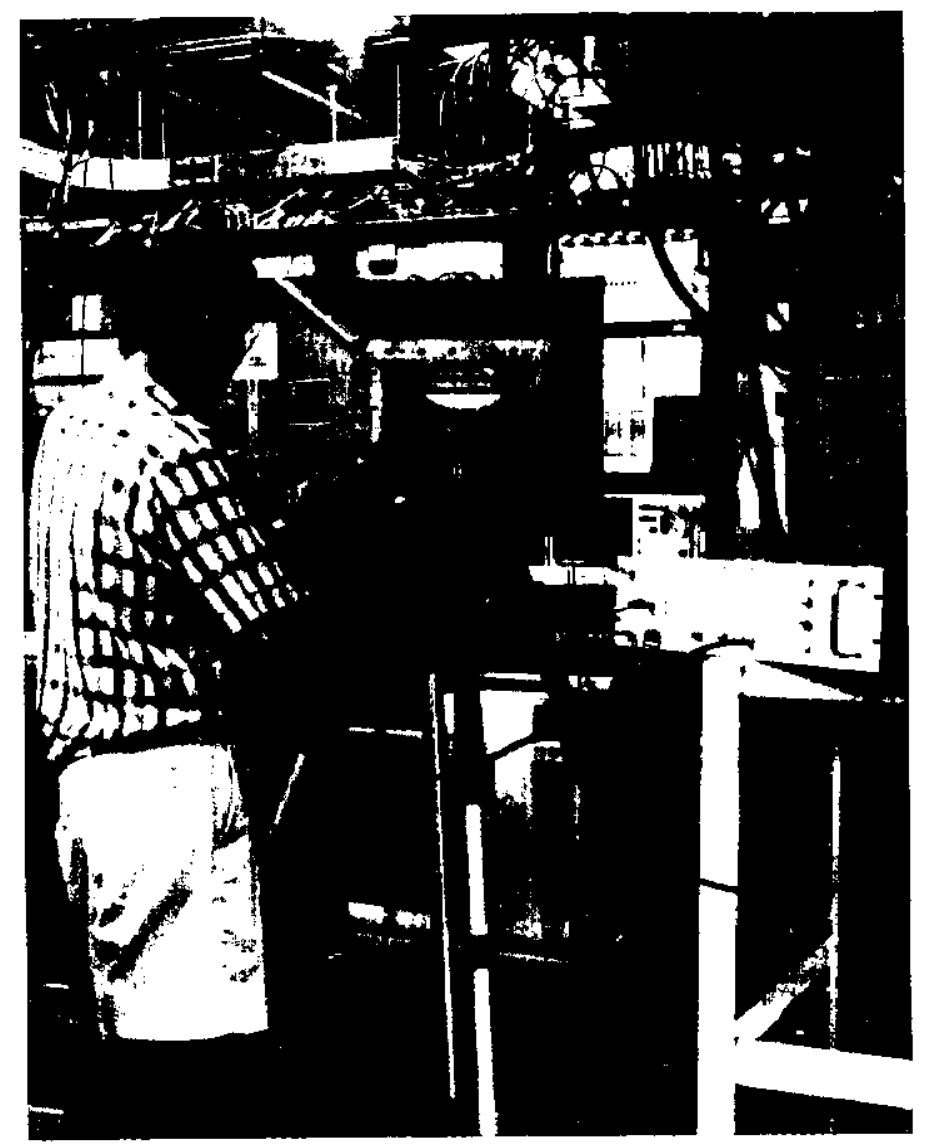

Figure 20 


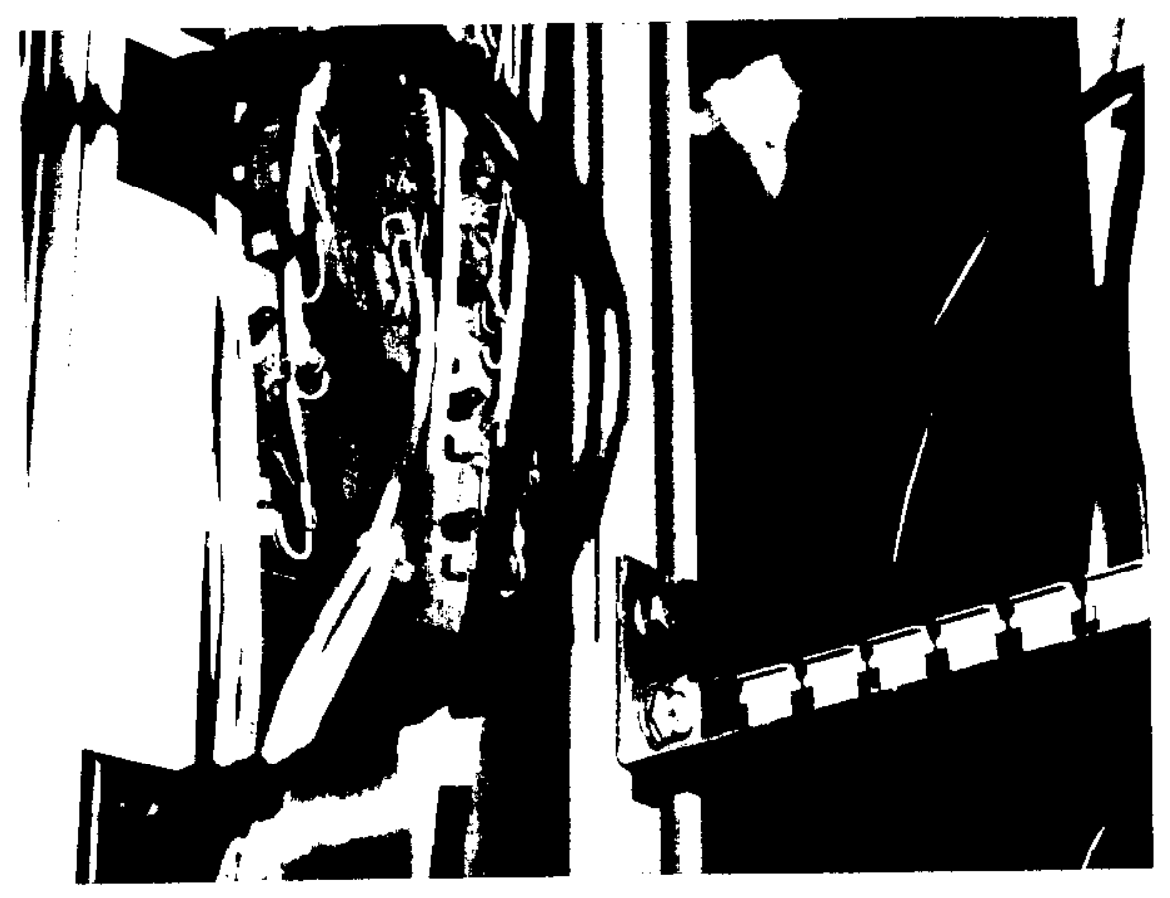

Figure 21.

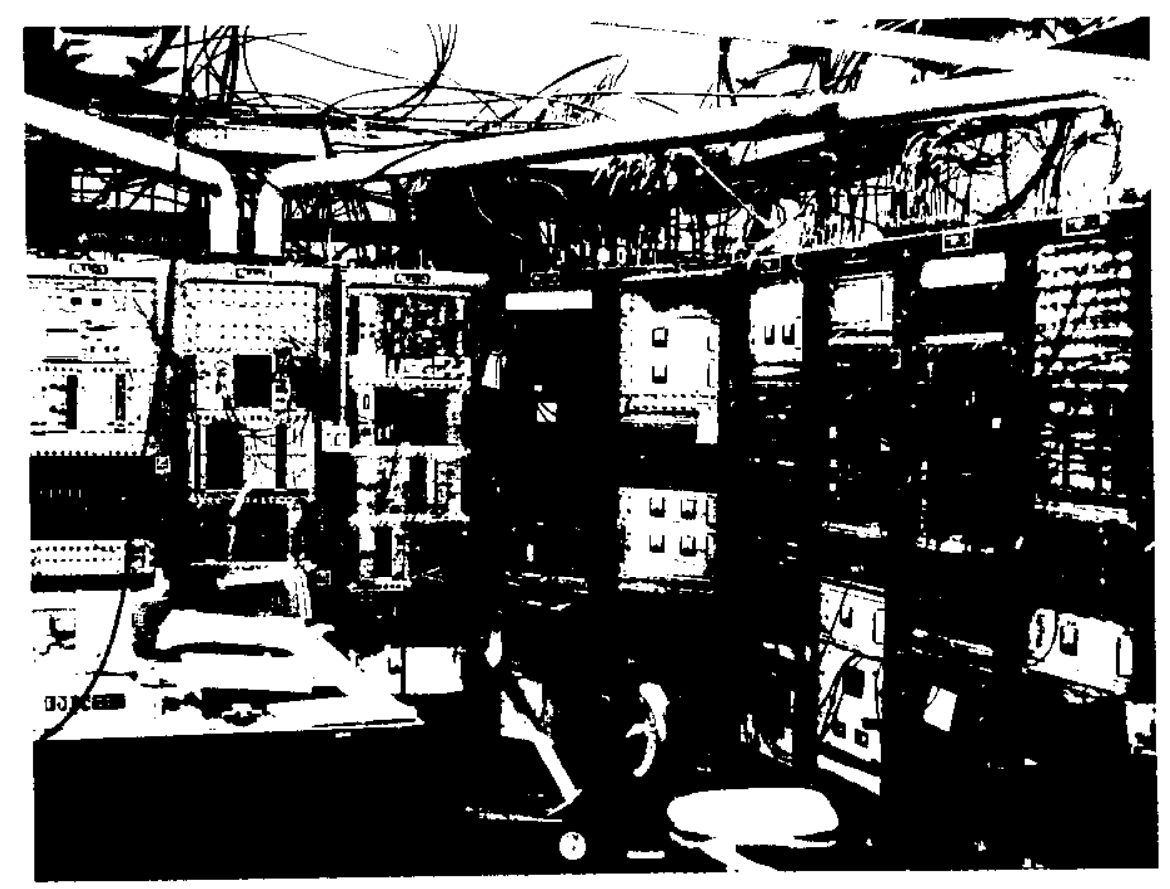

Figure 22. 


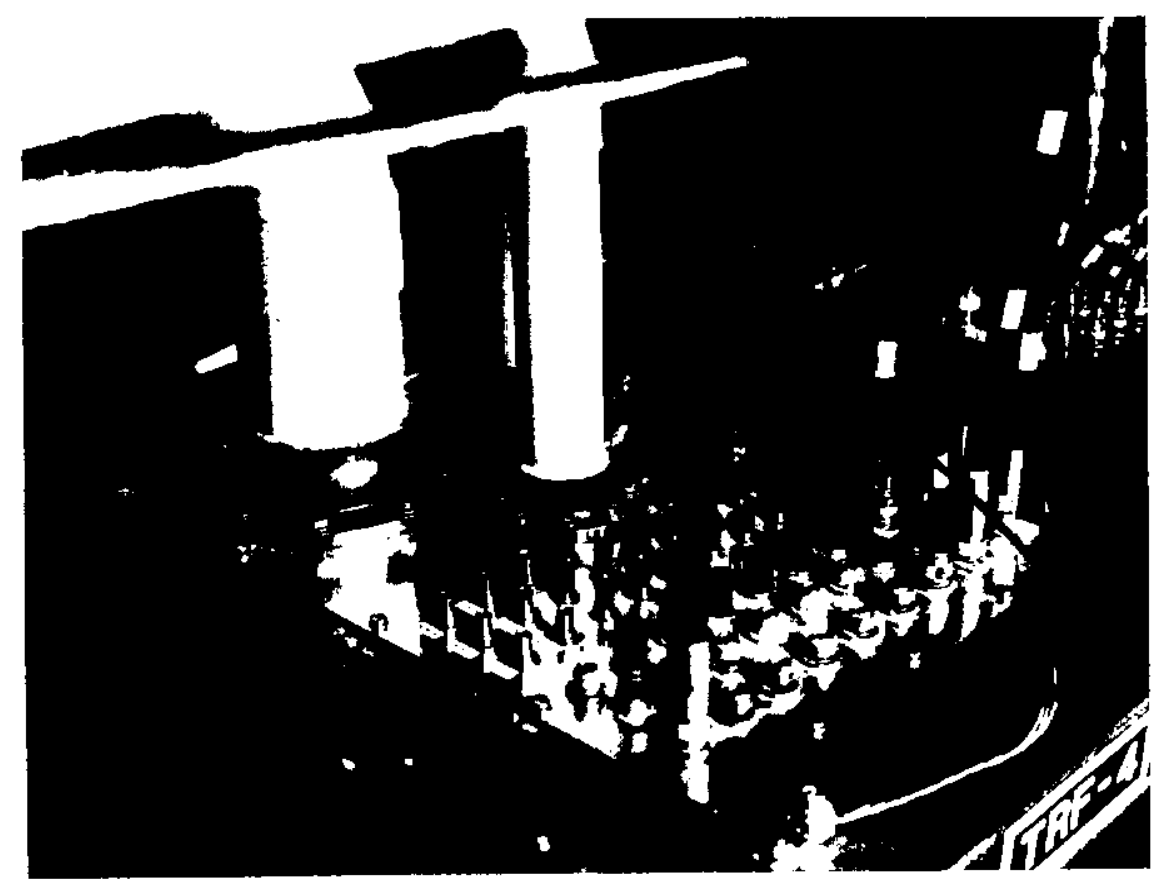

Figure 23 . 


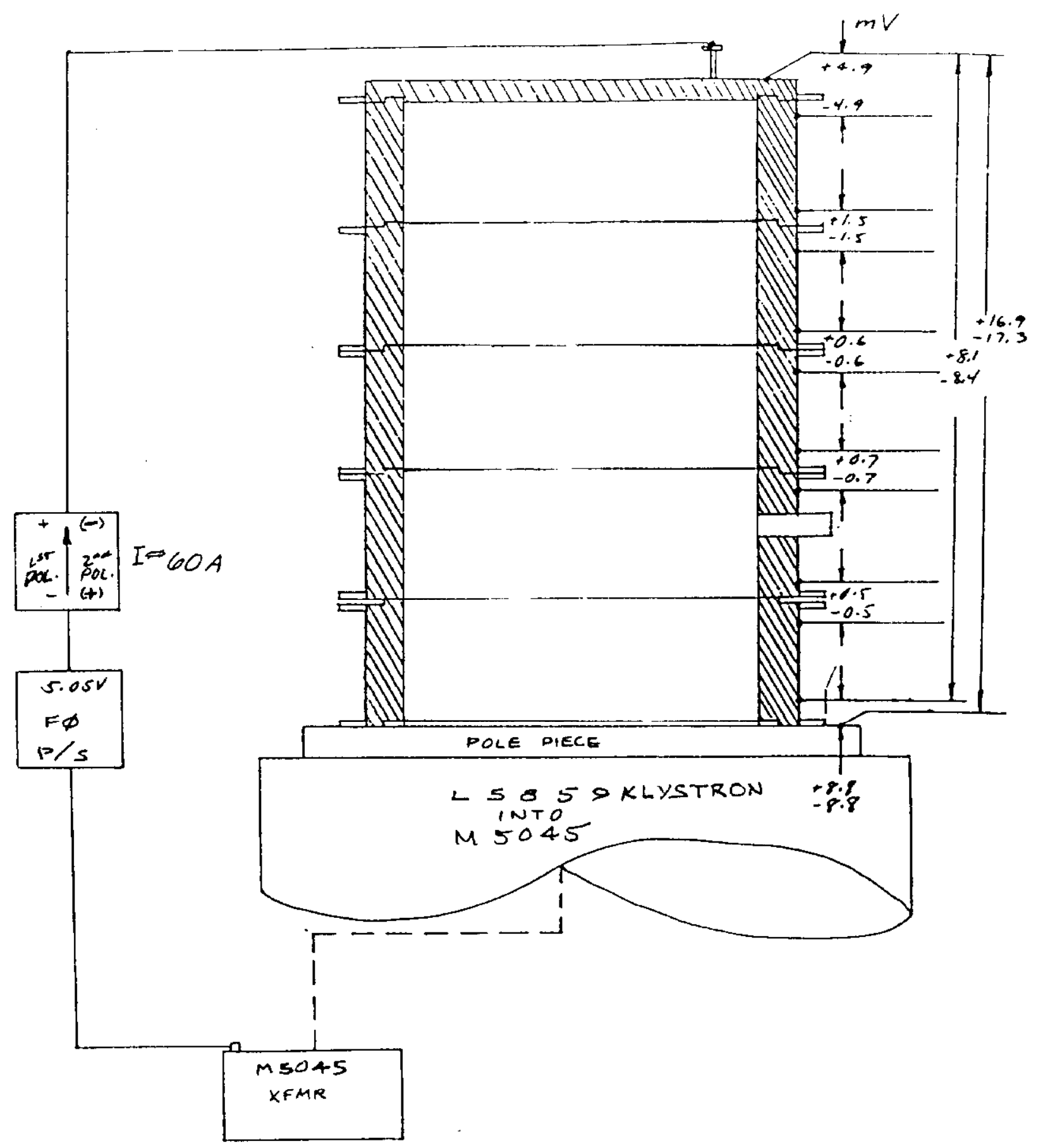

Figure 24. 


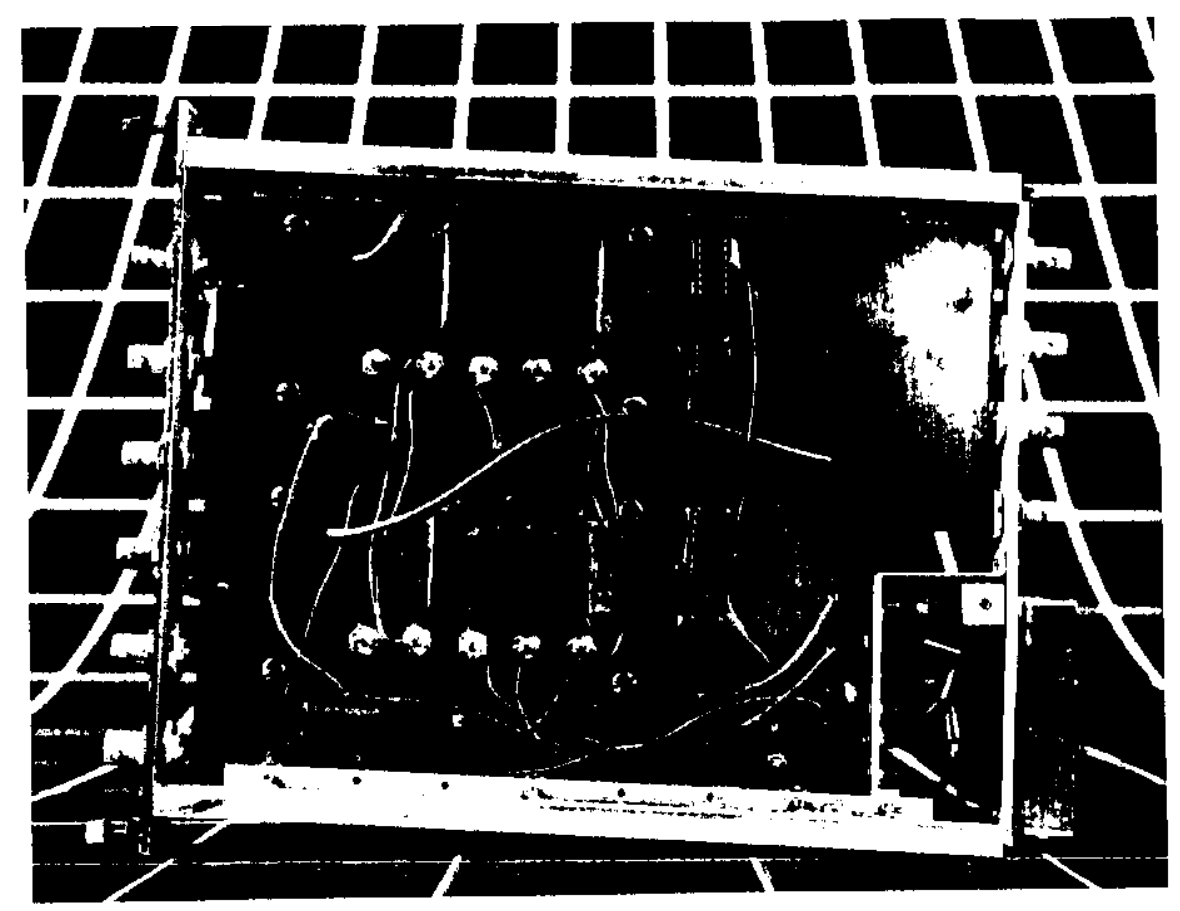

Figure 25.

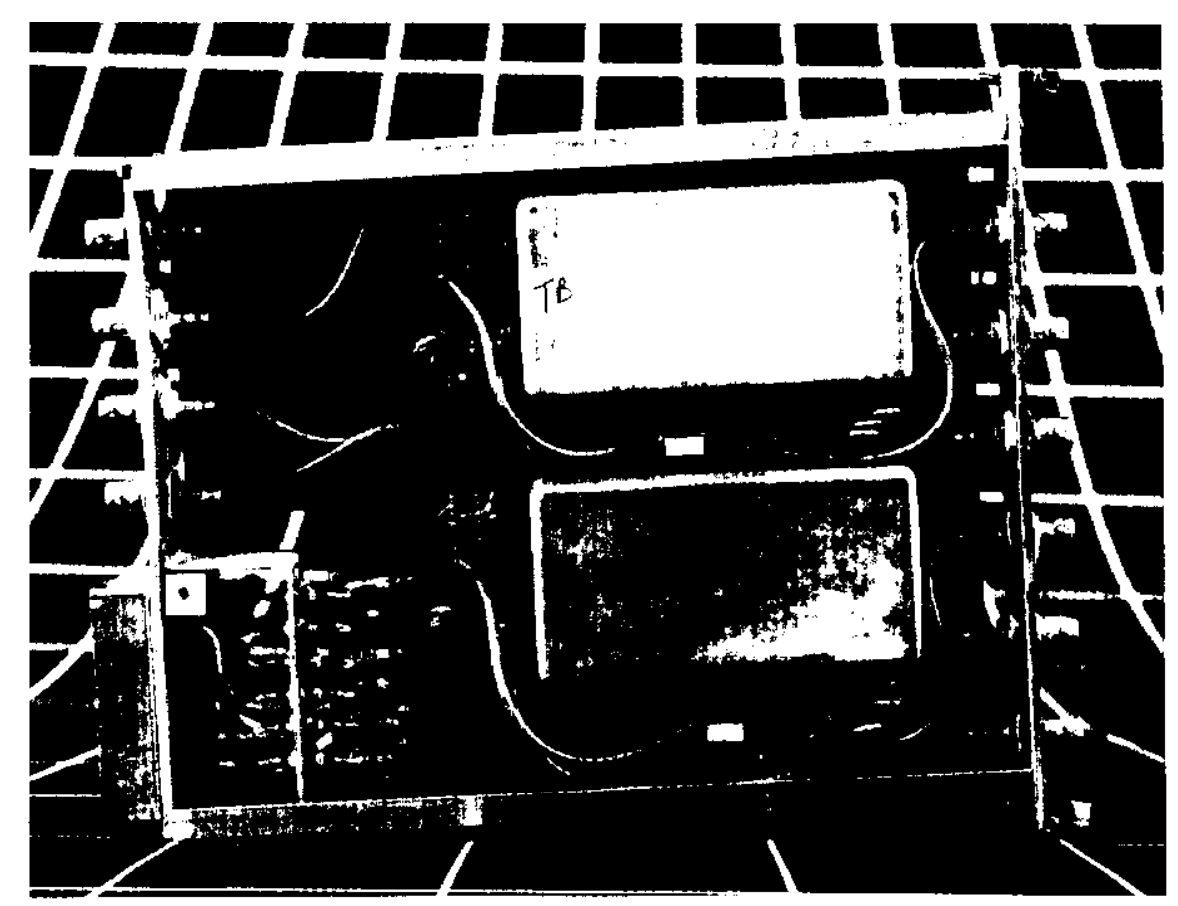

Figure 26. 


\section{ACTIVE NOISE REDUCTION}

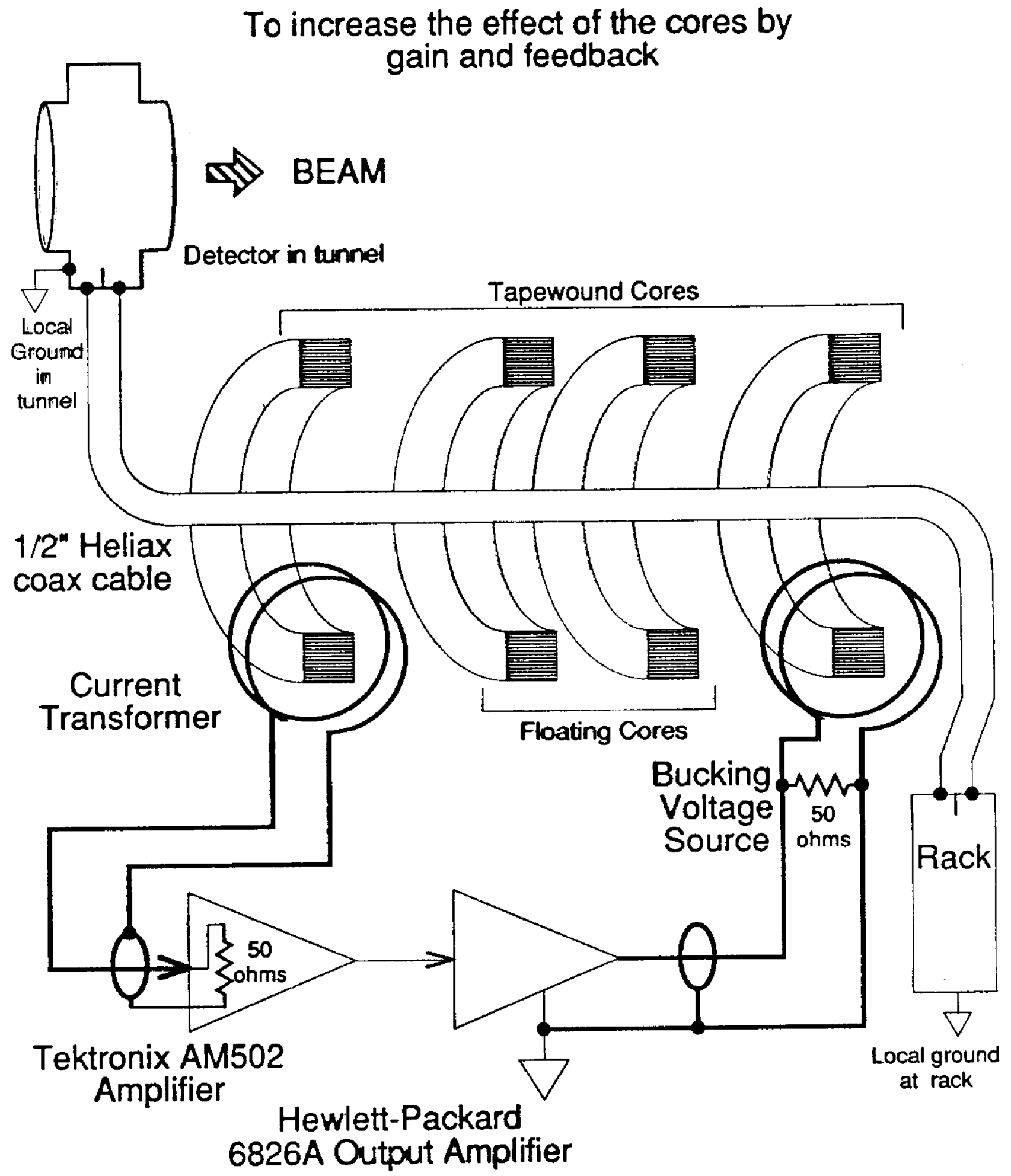

Figure 27. 


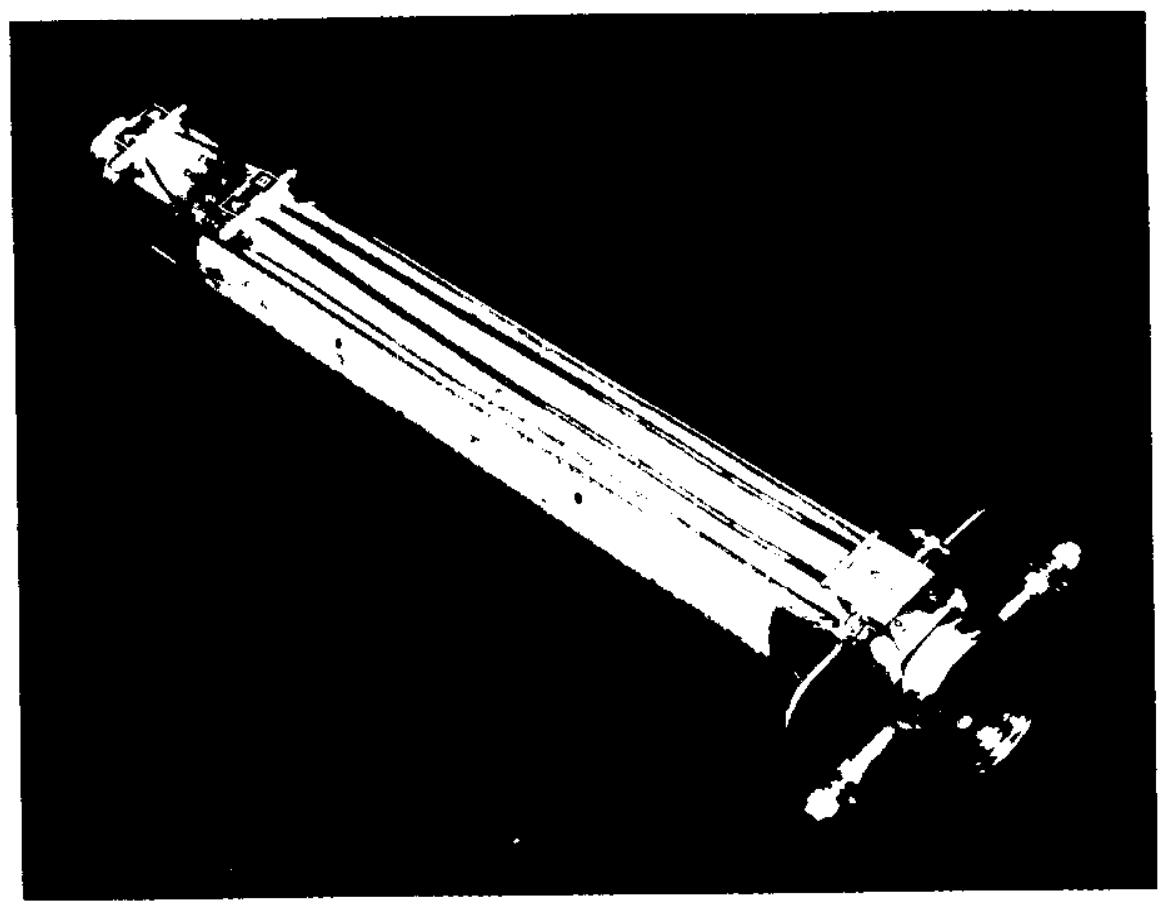

Figure 28.

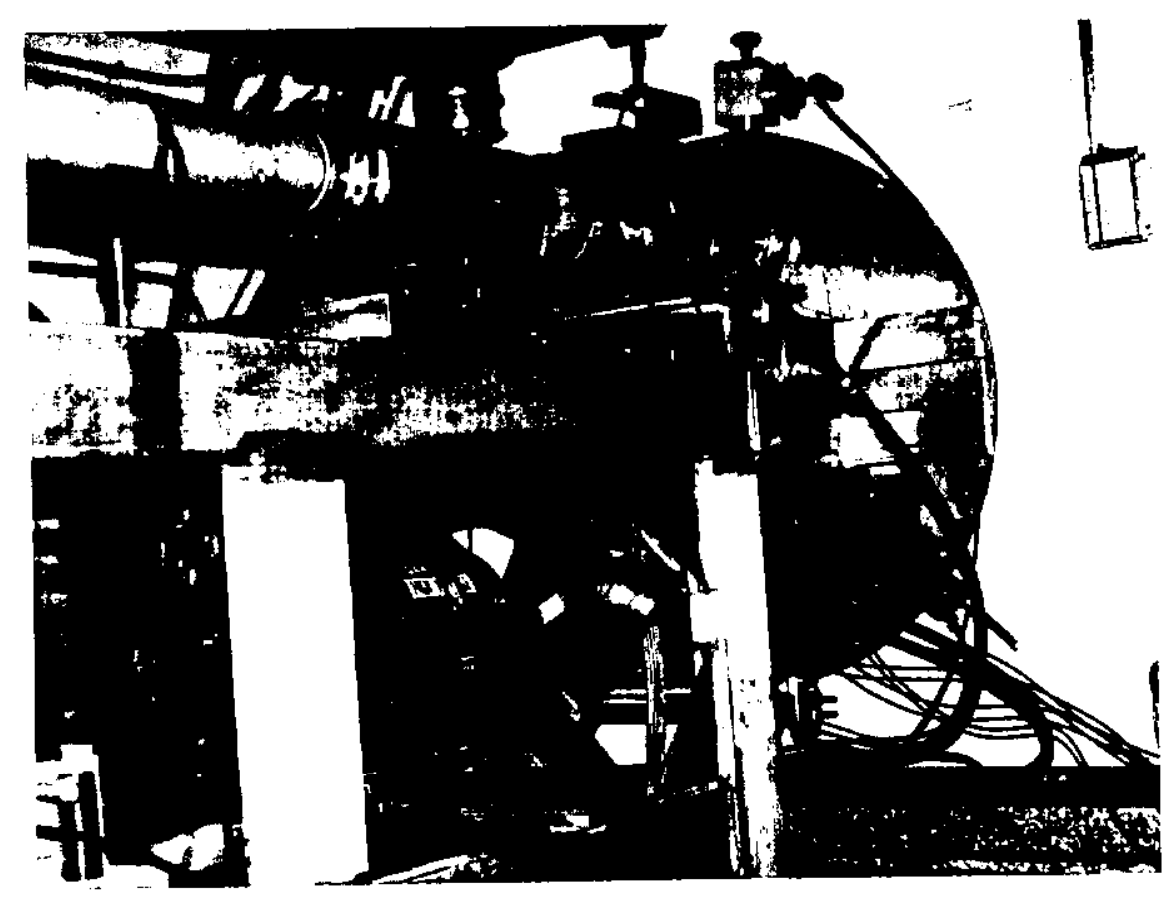

Figure 29. 


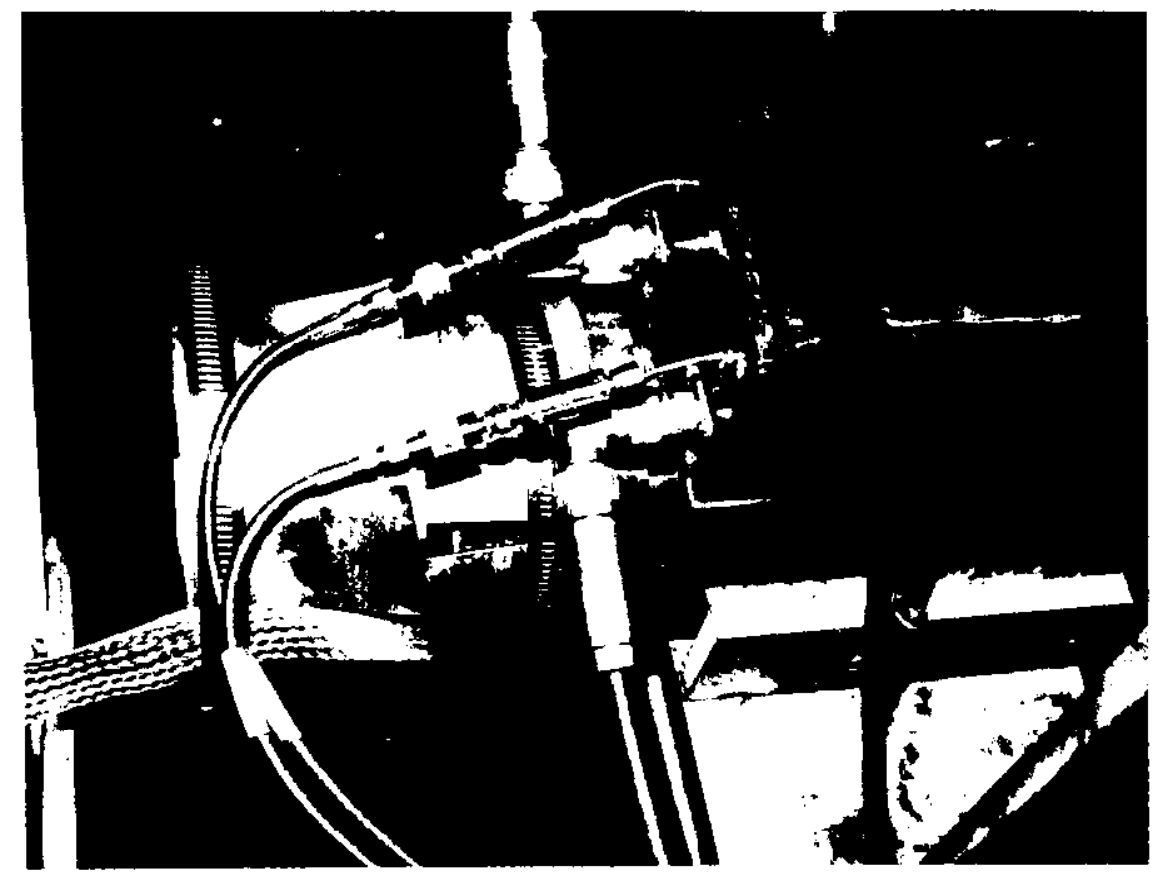

Figure 30. 


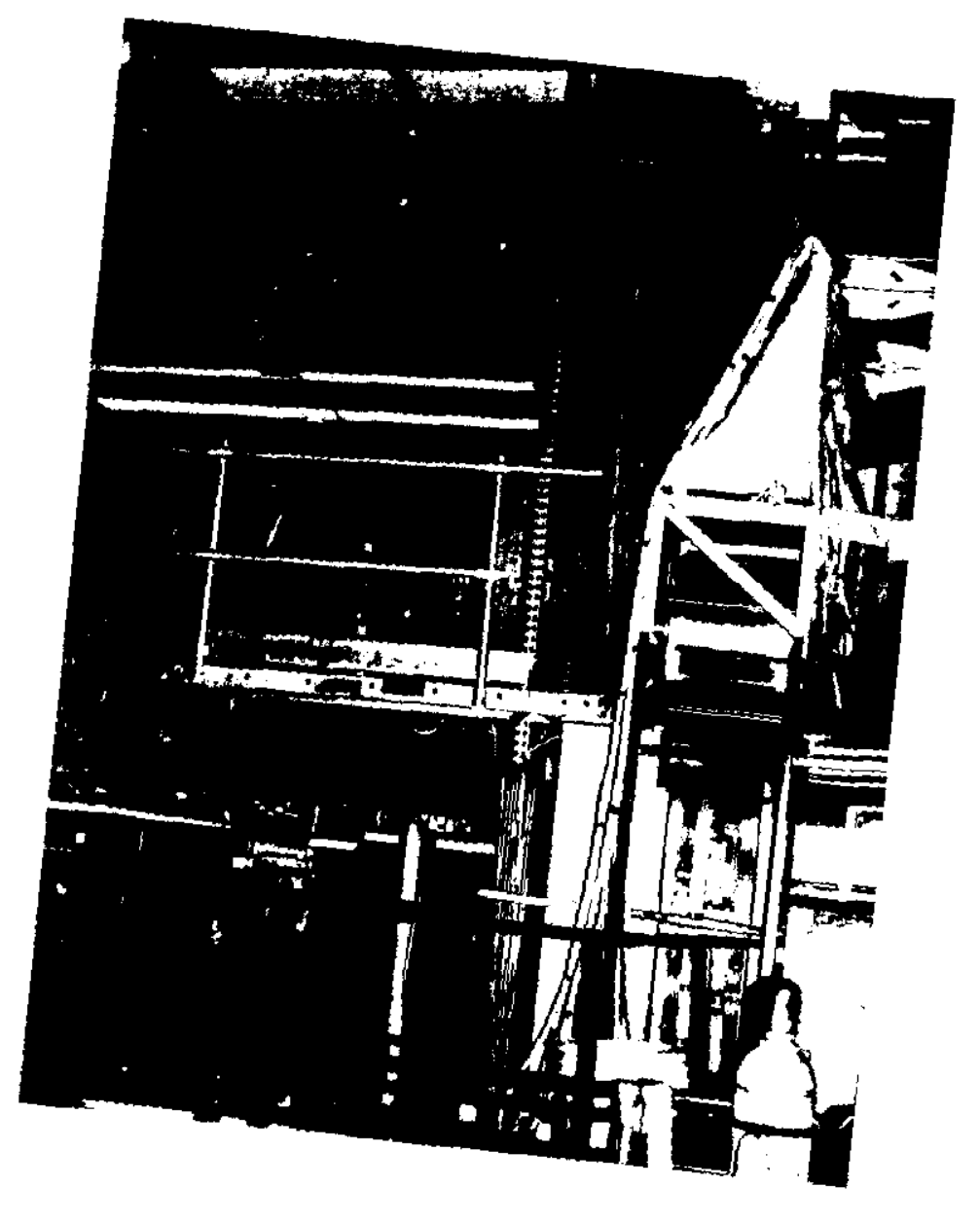

Figure 31. 


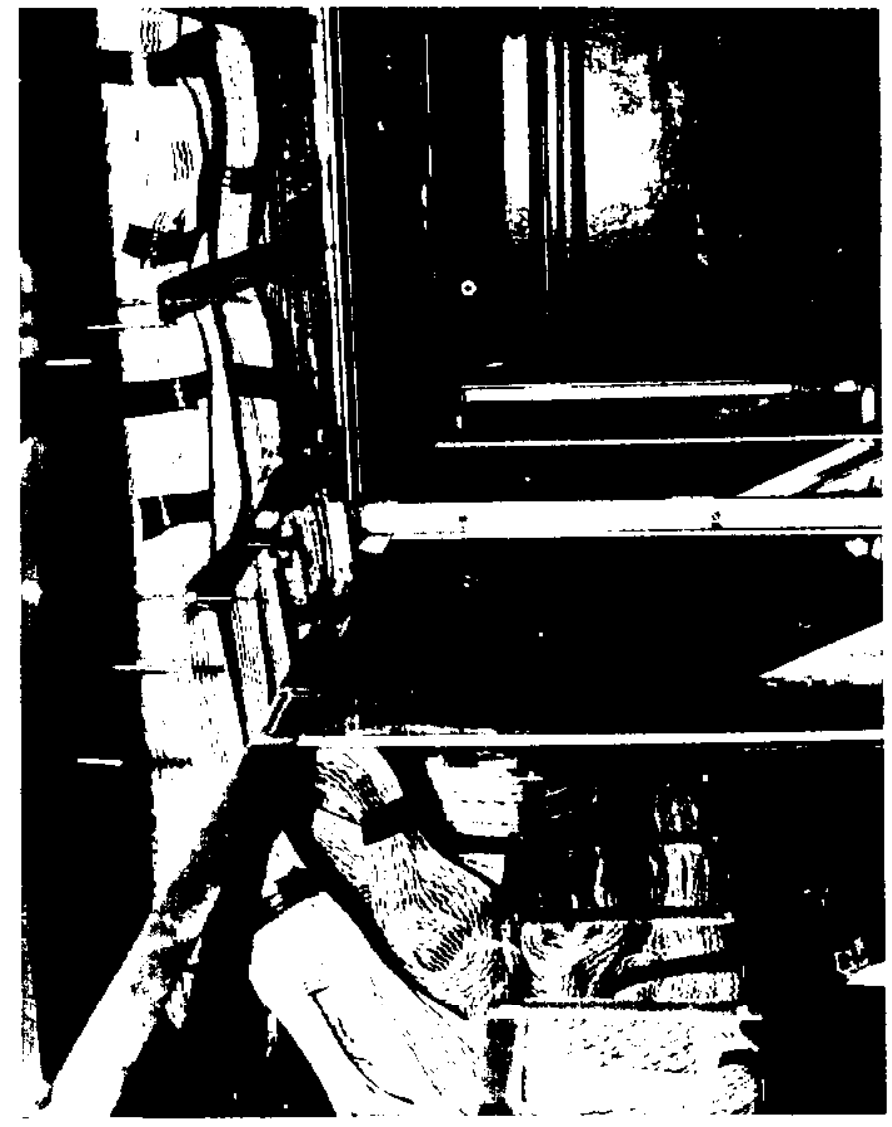

Figure 32. 


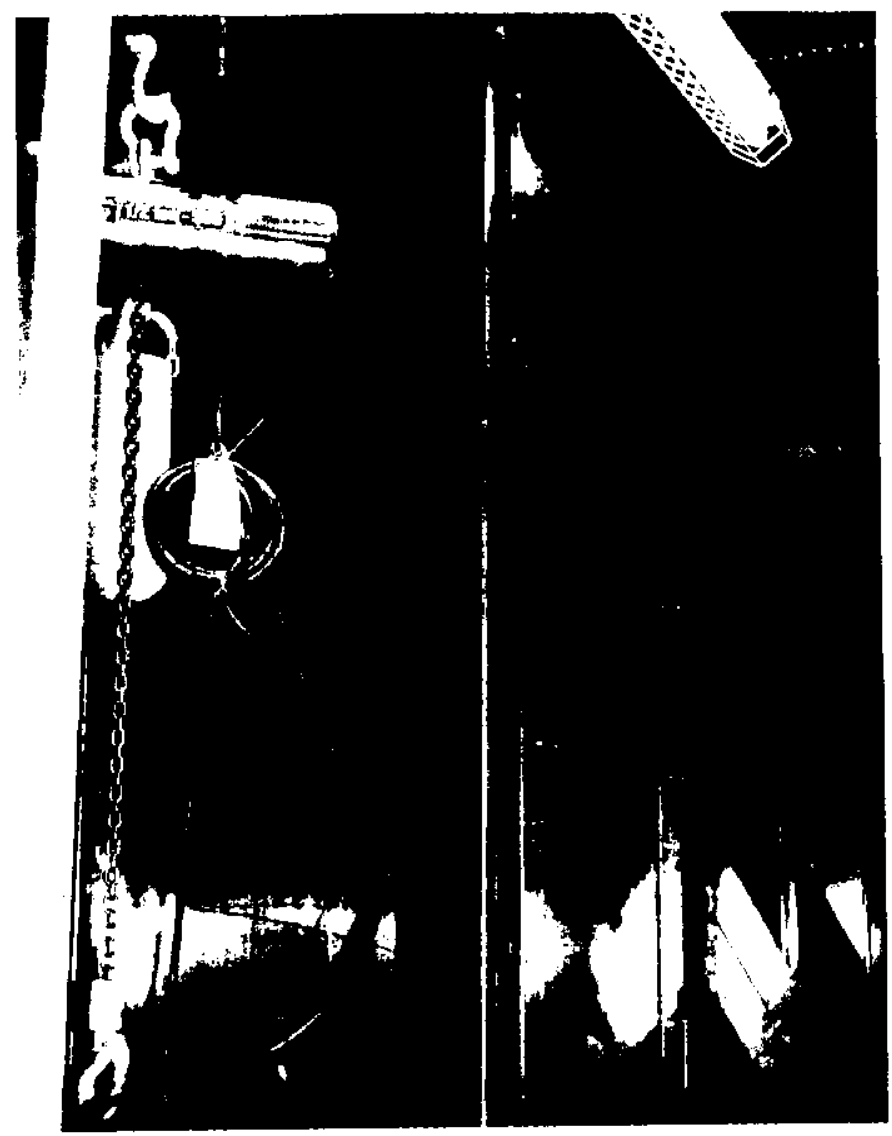

Figure 33. 


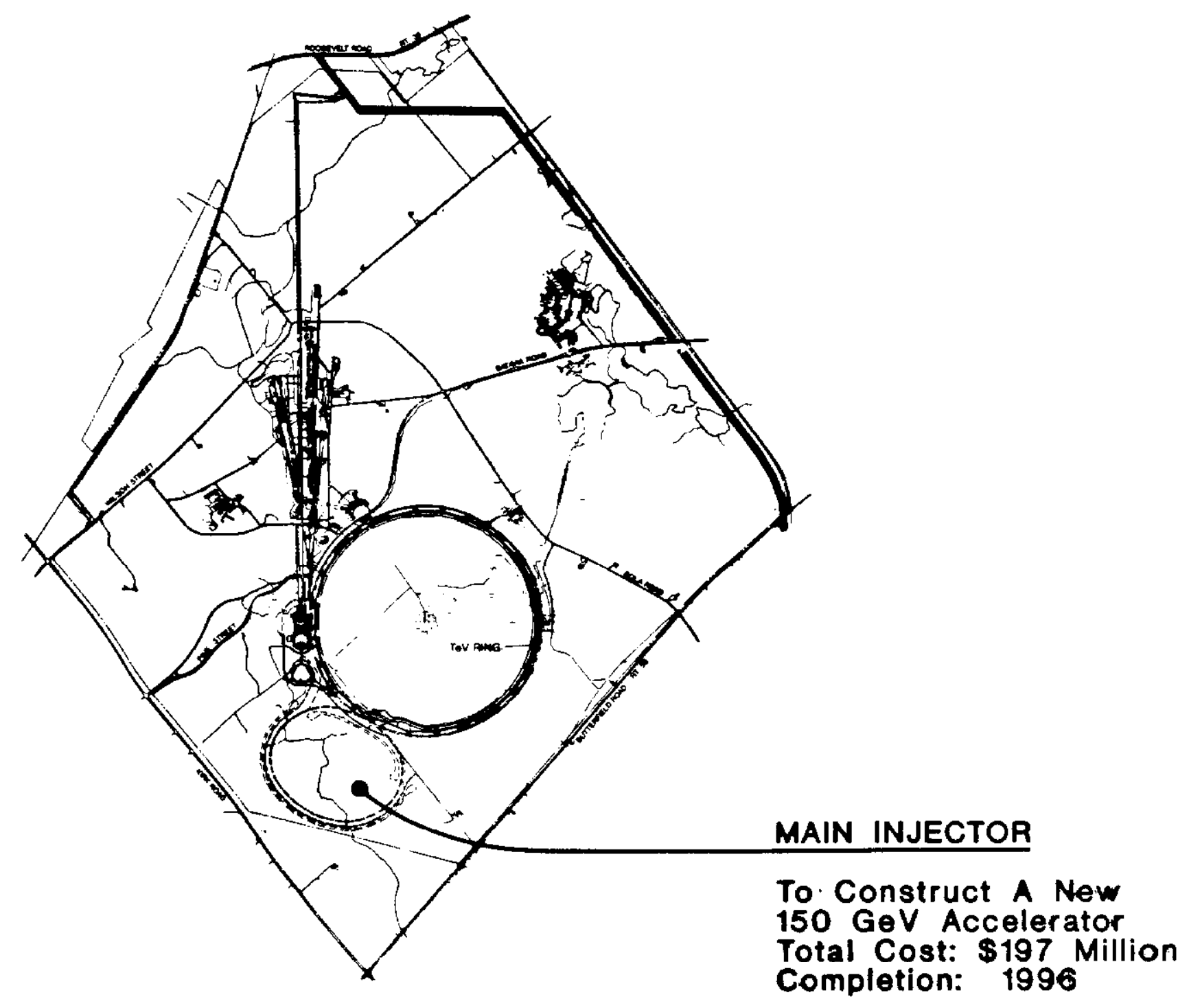

\section{FERMILAB}

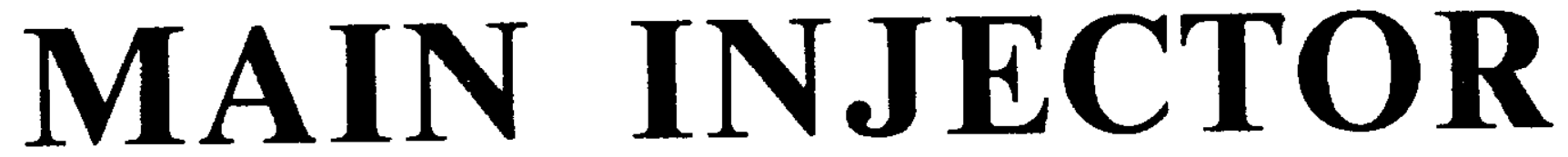

Figure 34 . 